\title{
Devletin Değişen Rolü Çerçevesinde Bağımsız İdari Otoriteler: Karşılaştırmalı Bir Analiz ${ }^{1}$
}

\author{
NAĞME Buse ŞENER (i) ${ }^{2}$
}

Başvuru: 03.06.2020; Düzenlenme: 23.06.2020; Kabul: 29.06.2020

\begin{abstract}
Yirminci yüzyılın son çeyreği itibariyle birikim rejiminde değişim yaşanmış, ekonomi politikaları bu değişim ekseninde yeniden şekillenmiştir. Bu dönemde ekonomi politikalarında uygulama alanı bulan yeni liberal politikalar pek çok alanda kendini göstermekle birlikte, devlet anlayışında değişimi getirmiş ve kamu yönetimi alanında da önemli yapılanmalar ortaya koymuştur. Bağımsız idari otoriteler bu yeni yaklaşımın idare yapılanması içerisinde vücut bulmus halidir. Çalı̧ma kapsamında öncelikle devletin dönüsüm süreci tarihsel perspektifte incelemiştir. Bu sürece paralel olarak yirminci yüzyılın sonlarından itibaren kamu hiyerarşisinde önemli roller üstlenen bağımsız idari otorite yapılanması ele alınmıştır. Türkiye açısından bu kurumların yapıları ele alınmakla birlikte seçilmis ülke ve ülke gruplarında bu yapılanmaların durumu karşılaştırmalı olarak analiz edilmiştir.
\end{abstract}

JEL kodları: F02, G28, G38, H10

Anahtar kelimeler: Devletin Değişen Rolü, Bağımsız İdari Otoriteler, Neoliberalizm

\section{Giriş}

1980'lerde devlet düzeni derin bir dönüşüm sürecinin içerisine girmiş; bu süreçte devletçi yapıdaki ekonomi, rekabetçi piyasa ekonomisi ile yer değiştirmiştir. $\mathrm{Bu}$ değişim ile devlet üretici kimliğinden sıyrılmış; devletin görev ve yetkilerindeki değişmeye paralel olarak kamu yönetimi yapılanması da değişmiş, aynı zamanda kamusal nitelikteki hizmetlerin görülmesi de teknik olarak değişim sürecine girmiştir.

\footnotetext{
1 Bu makale "Devletin Değişen Rolü Çerçevesinde Bağımsız İdari Otoritelerin Türkiye'deki Uygulamaları ve Kamu İhale Kurumu Örneği " başlıklı yüksek lisans tezinden türetilmiştir

${ }^{2}$ Sosyal Bilimler Enstitüsü, Ankara Üniversitesi, Ankara, Türkiye. (e-mail: nbsener@gmail.com)
}

Kısacası devlet düzenleyici ve denetleyici bir kimlik kazanmıştır. Devlet anlayışında yaşanan değişimler, bu durumun doğal bir sonucu olarak, ülkelerin idari yapılanmalarına da yansımış, yeni devlet anlayışı kendilerine özgü kurumsal yapılanmalarını oluşturmuştur. Öngörülen serbest piyasa ekonomisi içerisinde düzenleyici ve denetleyici role sahip olan devlet bu görev ve yetkilerini "bağımsız idari otoriteler" olarak anılan kurumsal yapılar eliyle kullanmaya başlamıştır. Piyasaların düzenlenmesi ve denetlenmesi işlevinin etkin olarak yerine getirilmesinin sağlanması noktasinda önem arz eden bu kurumlar oluşturuldukları ülkenin siyasi, iktisadi ve sosyal yapısina göre farklı özellikler 
kazanmışlardır. Bu kurumlar ilgili dönemde yaşanan özelleştirme furyasının ardından bankacılık, finans, enerji, sermaye piyasası gibi sektörlerin doğal tekel yapılarının değişmesi sonrasinda bu alanlarda aksaklıkların yaşanmaması, özelleştirmelerin özel tekele neden olmaması, iktisadi faaliyetlerin düzenlenmesi ve denetlenmesi gibi amaçlarla kurulmuşlardır.

Çalı̧̧mada devlet anlayışındaki bu dönüşüm ve bağımsız idari otorite yapılanmasına yönelen süreç tarihsel olarak ele alınmış, uygulama açısından önemli ülke örnekleri ve Türkiye örneği ele alınmıştır. Karşlaştırmalı yapılan inceleme sonrasında Türkiye örneği üzerinden genel değerlendirmelere yer verilmiştir.

\section{1900'lü Yılların Başında Devlet Düzenindeki Değişmeler}

Devlete yüklenen roller zaman dilimleri arasında, yaşanan konjonktürel gelişmelere bağlı olarak önemli farklılıklar göstermiştir. "Liberalizm doğduğu zamandan beri küçük devleti yüceltmekte, Marksizm bu tarihsel nesnenin sönüp gideceğini öngörmekte, Anarşizm ise devletin söndürülmesi için hemen ve şimdi harekete geçilmesini istemektedir" (Güler, 2005).

19 uncu yüzyılın sonlarma kadar "Klasik Devlet" veya "Geleneksel Devlet" olarak adlandırılan devlet anlayışı ağır basmıştır. Klasik devlet anlayışında, devlet sadece milli savunma, güvenlik, adalet hizmetlerini sunmakla yükümlü olup; bu yapının toplumun korunmasına odaklı bir sistem olduğunu söylemek yanlış olmayacaktır. Ancak "esas olarak 1873 'te başlayan büyük depresyondan itibaren, liberal dönem, ticaret politikasında gözle görülür alt üst oluşla birlikte sona ermiştir" (Habernas, 2010). 1920'li yıllarda yaşanan gelişmeler ile birlikte de Klasik Devlet anlayışı yerini daha müdahaleci yapıya sahip olan bir anlayışa bırakmak durumunda kalmıştır. 1920 yılında Tokyo Borsası'nın düşmesi ile başladığı kabul edilen ve Büyük Buhran olarak da adlandırılan 1929 Dünya
Ekonomik Bunalımı olarak bilinen küresel kriz ile birlikte, mevcut hâkim görüşe ilişkin soru işaretleri oluşmaya başlamış; 2. Dünya Savaşı ve sonrasindaki dönem ise, devletin ekonomik hayata müdahalesinin ve toplam talep yönetiminin gerekliliğini tam anlamıla ortaya çıkarmıştır.

Piyasa mekanizması ekonomide eşit koşullarda var olan, kar elde etmeye çalışan aktörleri varsayar (Ekiz, 2010). Klasik iktisadi yaklaşım çerçevesinde piyasaların kendi haline birakılması durumunda piyasa koşullarının adeta bir görünmez el varmış gibi kendiliğinden dengeye geleceğini savunan A. Smith'in "görünmez el" ile kastettiği aslında ekonomik aktörler arasında var olan, olması beklenen rekabettir. Kısacası bu bakış açısında "müdahaleci devlet insanlığın başındaki başat musibet" (Güney, 2006) olarak sunulmaktaydı. Ancak yaşanan küresel ölçekli kriz ile "Görünmez El" yardımı ile kaynakların optimum dağılıma sahip olacağı yönündeki hakim görüş önemli ölçüde zarar görmüss, piyasa aktörlerinin serbest rekabet ortamındaki başarısızlığı su yüzüne çıkmıştır. Say Yasası da, bunalımların aşılmasında sistem dengesinin hiç de mevcut üretici güçlerin ulaşılabilecek en yüksek düzeyinde otomatik olarak oluşmamasıyla iflas etmiştir (Habernas, 2010). Devlet, yaşanan başarısızlıkların ve gelişmelerin bir sonucu olarak üretim, mübadele ve dağıtım süreçlerinde etkin olarak rol almaya başlamış, devlete atfedilen görevler eskisine kıyasla önemli ölçüde değişmiş ve gelişmiştir. Ortaya çıkan bu yeni devlet yapılanması olan refah devleti, gelişmiş ülkelerde, milli gelirin adil dağılımını ve bireylerin asgari yaşam standardının sağlanması sorumluluğunu üstlenen devlet olarak tanımlanabilir. Hemen hemen yakın anlamlarda kullanılan refah devleti ve sosyal devlet milli gelirden herkesin anlamlı ve orantılı pay almasinı öngören bir devlet modelidir.

1929 Dünya Ekonomik Bunalımı'nın sonrasında yaşanan gelişmeler ışı̆̆ında piyasa ekonomisinin, kendiliğinden tam istihdam yaratmadığı ve devletin müdahalesi olmadan 
piyasanın mevcut aksaklıklarının giderilemeyeceği düşüncesi ile Keynes tarafindan öne sürülen talep yönlü, kamu harcamaları yolu ile ekonomik ve sosyal hayata müdahale edilmesini öngören "Tam İstihdam Teorisi" hızla yayılmaya, kabul görmeye başlamıştır. Keynes'in 1930'lu yıllarda teorik bütünlüğe kavuşturduğu biçimde devletin ekonomiye müdahale ederek yönlendirilmesini öngören bu anlayış, 2. Dünya Savaşı'nın bitiminden itibaren uygulamaya geçmiş ve 1970'lere kadar da etkisini sürdürmüştür. "İkinci Dünya Savaşı sonrasında başlayan ve 1960'lı yılların ortalarına kadar süren yeni gelişme aşaması "tekelci kapitalist düzenleme" ve "Fordizm" dönemi olarak da adlandırılan sosyal/refah devleti dönemidir" (Güzelsarı, 2004b).

Keynes'in düşünceleri ekseninde oluşan bu yaklaşım pek çok Avrupa ülkesinde uygulama alanı bulmuş, büyümenin sağlanması, tam istihdam seviyesine ulaşılması, fiyat istikrarının sağlanması temel ve ortak amaçlar olarak benimsenmiştir. Bunların yanında sosyal devlet olmanın getirdiği doğal bir sonuç olarak sosyal güvenlik harcamaları, sosyal fonlar ve sosyal yardımlara da özel önem verilmeye başlanmıştır. Devlet, işsizliğe önem vermiş, fiyat istikrarını, iktisadi denge ve ödemeler dengesinin sağlanması gibi çeşitli amaçlarla, ekonomiye doğrudan müdahale etme yolunu tercih etmiştir.

Türkiye açısından bakıldığında özellikle 1930-1932 yılları arası, "Devletçilik" faaliyetlerine özel önem verildiği ve bu faaliyetlerin geliştirilmesi yönünde çabaların yaşandığ 1 bir dönem olmuştur. Cumhuriyetin kurulması ile birlikte kamu girişimciliği faaliyetlerinde artış görüşmüştür, ancak "devletin tam olarak ekonomiye nüfuz etmesi, iktisaden faal hale gelmesi, devletçilik ilkesinin ilk önce 1931'de Cumhuriyet Halk Firkası Kurultayı'nda ve daha sonra da Anayasal ilke olarak kabul edildiği 1933 yllından itibaren olmuştur" (Ekiz, 2010). Yani ülkemizde de, küresel örneklerdeki gibi "1929 yılı sonrasında süreç, devletin plan yaparak, organize ederek ve denetleyerek ekonomiye müdahale ettiği bir dönem olmuştur" (Kaya, 2004).

\subsubsection{Düzenleyici Devlete Geçiş Süreci} Çerçevesinde Devlet Anlayışına Genel Bakış

1967 yılına gelindiğinde yeniden ekonomik durgunluk baş göstermiş ve beraberinde de geniş çaplı krizi getirmiştir. "İkinci Dünya Savaşı'nın ardından 1970'lere kadar uzanan dönemde Altın Çağı"nı yaşayan dünya kapitalizmi, sonrasındaki süreçte düşen kâr oranlarıyla birlikte ekonomik ve toplumsal dengeleri derinden sarsan yeni bir bunalıma girmiştir" (Güzelsarı, 2004a). Önemli politika değişiklikleri çok çeşitli nedenler ile ortaya çlkabilmekteyken, bunlardan en önemlilerinden biri krizlerdir ve "krizler mevcut siyasi rejimin sürdürülemez olduğuna işaret sayllırlar" (Öniş ve Şenses, 2007). 1970'li yıllar ayn zamanda para düzeninde önemli değişikliklerin yaşandığı bir dönem olmuştur. 1944 Bretton Woods Antlaşması ile oluşturulan sabit kur sistemine dayalı para düzeninin terk edilmesi, 1929 yılındaki ekonomik bunalımdan sonra ortaya çıkmış ve bu döneme kadar etkin ve yaygın bir biçimde uygulama alanı bulmuş olan Keynesyen yaklaşımın terk edilmesi sonucunu doğurmuştur. Zaten mevcut etkisini yitirmiş olan refah devleti anlayışını, tüm bu olumsuz gelişmelerin devamında yaşanan 1973 Dünya Petrol Krizi daha da yıpratmıştır. Bu dönem 1945 yılı sonrasında oluşan refah devleti anlayışının sorgulanmasını aşmış, yerine neoliberal devlet anlayışının tam olarak konulmasına neden olmuştur. Kapitalist sistemin yaşadığ 1 bunalımın neoliberal ideolojiyi doğurduğunu (Güzelsarı, 2004a) söylemek doğru olacaktır. Bu sürecin başlamasıyla rekabetçi piyasa ekonomisinin sağlanması ve devletin küçültülmesi amacına dayalı olarak politikaların yürütüldüğü, özelleştirme ve deregülasyon yönünde çabaları arttığı bir dönem ortaya çıkmıştır. Zaten neoliberal olarak adlandırılan bu yeni liberalizmin te- 
melini devletin piyasa ekonomisi üzerindeki aktif rolünün tamamen ortadan kalktığ 1 , asgari görevlerin üstlenildiği bir devlet modeli oluşturur.

Daha öncesinde kamu sektörü tarafindan sunulan çeşitli görevlerin serbest piyasaya bırakılması, yalnızca temel kamusal nitelikli faaliyetlerin devlet tekeline birakılması anlayışına dayanan neoliberal politikalar özünde devletin küçülmesi, piyasa düzeninin gelişmesi anlayışına dayanmaktadır "Yeni Sağ" da denilen bu uygulamalarm Türkiye'de temelleri 24 Ocak 1980 kararları ile atılmıştır. Yeni sağ anlayış minimal devleti öngörmenin yanında serbest piyasa düzeninin kurulması için kamu sahipliğindeki işletmelerin, piyasadaki eşitlikçi yapıyı bozduğu gerekçesiyle özelleştirilmesi gereğini de savunmaktadır. "Yaşanan gelişmeler sonrasında 24 Ocak 1980 kararları ile birlikte "serbest" piyasa ekonomisine geçiş doğrultusunda kamu kesiminin mal ve hizmet üretim alanları özel kesime devredilmek suretiyle aşamalı olarak daraltılmıştı" (Ekiz, 2010).

Görüldüğü üzere yeni liberal anlayış çerçevesinde "deregülasyon" ve "özelleştirme" özel öneme sahip duruma gelmiştir. Deregülasyon, kuralsızlaştırma anlamina gelmektedir ancak her ne kadar bu anlama gelse de, bu kuralsızlaştırmanın sağlanması için dahi kurallara ihtiyaç duyulacağı bir gerçektir. Aslında deregülasyon yerine "yeniden düzenleme" kavraminın kullanılması çok daha anlamlı olacaktır. Çünkü özelleştirme çabaları ekseninde, kamusal hâkimiyete son verilmesi söz konusu iken, bir yandan bu özelleştirme hareketleri kapsamında düzenlemeler gerekli olmakta, serbest piyasa ekonomisin oluşması ve etkin, verimli işleyebilmesi için yeni oluşan yapının düzenlenmesi ve denetlenmesi gereği düzenleme faaliyetleri gerçekleştirilmektedir. Görüldügü gibi özelleştirme ve deregülasyon aynı zamanda iç içe geçmiş kavramlardır. Özelleştirme hareketleri ile beraber devletin ticari faaliyetlerden uzak durması, ancak bunun yanında denetleyici rolünün devam etmesi amaçlanmaktadır. 1970'li ylllarda baş gösteren ve özellikle 1980 sonrası hız kazanan kamu yönetimi alanındaki gelişme ve değişmeler, küreselleşme ekseninde neoliberal politikalarm uygulanması ile ortaya çıkmıştır. "Kriz ve yeniden yapılanma süreci kapitalist ekonomilerin yapısını değiştirdiği gibi kamu yönetimi yapılarını ve örgütlenmelerini de değiştirmiştir" (Güzelsarı, 2004a). Uygulanan müdahaleci, sorumlu devlet anlayışından uzaklaşılıp minimal, düzenleyici devlet anlayışına geçildiğinde, yeni oluşan yapının, serbest piyasa ekonomisinin işlerliğini sağlaması önemli hale gelmiştir. Düzenleyici anlayışta hem devletin hizmet sunumundaki başarısızlıklarının giderilmesi, hem özelleştirilen sektörlerde başına buyrukluğun oluşturulmaması, hem de gelişen teknolojik değişimlere ayak uydurulması adına düzenleme faaliyetlerine girişilmektedir (Bhattacharya ve Patel, 2003). Devletin müdahaleci kimliğinden kurtulmasının ardından, piyasaya ilişkin de düzenleyici mekanizmalara ihtiyaç artmıştır. Küreselleşme politikalarının devlete bakış açısını yansıtan, hükümet ve piyasa başarısızlıklarına çözüm oluşturabilecek ve düzenleme işlevini yerine getirecek bir yapılanma olarak bağımsız idari otoriteleri değerlendirmek doğru olacaktır. Devletin değişen yapısı ile literatürde önemli yer edinmiş diğer iki önemli kavram da "yönetişim" ve "yeni kamu işletmeciliği" olmuştur. Müdahaleci devletten düzenleyici devlete geçiş, aynı zamanda kamu yönetimi anlayışından yeni bir kamu yönetimi anlayışına geçişi de işaret eder. Yeni kamu yönetimi anlayışı, kamunun var olan hantal bürokratik yapısından uzaklaşlıp, özel sektördeki gibi etkin karar ve uygulama süreçlerinin sisteme entegre edilmesini içerir. "Kamu yönetimine ilişkin bu yeni bakış açısı kamu sektörünün özel sektör gibi yönetilmesini, özel sektörün kullanımına hazır tekniklerinin ve değerlerinin de kamu yönetimine uyarlanmasını içermekte; vatandaşa müşteriymiş gibi davranmayı, kamu yöneticilerini de kamu politikalarını oluşturma 
sürecinden ayırmayı doğru bulmaktadır" (Sezen, 2002). Günümüzde düzenleyici devlet denince akla piyasa ekonomisinin düzgün işlemesi için gereken noktalara ilişkin düzenlemeleri yapan, düzgün işleyen piyasa ekonomisi için var olan devlet akla gelmektedir. Bağımsız idari otoriteleri bu iki kavram boyutunda anlamlandırmanın çok daha kolay olacă̆ı kanaatindeyim.

Yönetişim, kamunun karar alma süreçlerindeki değişime ilişkin iken; yeni kurumsal anlayış yönetim anlayışındaki idari değişikliği işaret etmektedir. Yönetişim kavramı ilk olarak; 1989 tarihli Dünya Bankası (DB) raporunda yer edinmiştir. Afrika'da krizden çıkış yolu olarak öngörülmüş olan bu model World Bank (1989)'ın geleneksel yapısındaki değişimi de ortaya çıkarmıştır. 1945 sonrasındaki süreçte yaşanan değişim ortamı uluslararası kurumların rol ve konumlarını da önemli ölçüde etkilemiştir. Birleşmiş Milletler'in kaybettiği değeri, IMF ve DB kazanmıştır. $\mathrm{Bu}$ yaşanan dönüşüm süreci uluslararası kuruluşların da dönüşümünü gerekli kılmıştır. 1989 tarihli yaşanan dönüşümün işareti olan rapor sonrasında, yönetişim kavramı ve uygulamalarına DB çalışmalarında sıklıkla yer verilmiş; 1992 tarihli raporda da kalkınma ile yönetişimin ilişkisi açık seçik gözler önüne serilmiştir (World Bank, 1992). Yönetişim, DB tarafindan bir ülkenin gelişmesi, kalkınmasının sağlanması adına kaynaklarının kullanılmasında iktidarın kullanılma biçimi olarak ifade edilmektedir (World Bank, 1994). İşte bă̆ımsız idari otoriteler yeni oluşan bu yapının, önemli ve vazgeçilmez bir parçası konumunda olup; iktidarın kullanılma biçimini göstermektedirler.

Çok aktörlü yönetim anlayışı neoliberal politikaların etkinsizliklerine bir çözüm olarak görülmüştür. Bu anlayışı ulus devlet anlayışının son bulmasını, ulus devletin sahip olduğu görev ve yetkilerin dikey olarak dağıtmasını, yani esasen daha doğru bir ifade ile sahip olduğu gücün büyük bir kısmını kaybetmesini öngörmektedir.
$\mathrm{Bu}$ yetkilerin dikey dă̆ıtımı bir kısmının ulus üstü kurumlara bir kısmının da yerel örgütlere devredilmesidir (Harmes, 2006). Neoliberal politikaların "daha az devlet, daha çok piyasa" söylemi ve devletin kamu merkezli müdahalelerinin yerini piyasa lehine düzenlemeler ve aynı zamanda piyasanın da dolduracă̆ gerçekleştirilmeye çalışılmış, özelleştirme 1990'lara gelindiğinde eski önemini kaybetmiş; yerini çok aktörlü yönetim ve yeni kurumsal bakış açısı almıştır. Bağımsız idari otoriteler, çok aktörlü yönetim modelini bir toplum ve devlet modeli olarak ete, kemiğe büründüren yapılar (Bayramoğlu Özuğurlu, 2005b) olmanın yanında, neoliberalizmin devleti yeniden yapılandırma stratejisinin bir ayağını (Güzelsarı, 2004b) da oluşturmaktadırlar. Bă̆ımsız idari otoritelerin devlete ilişkin meydana getirdiği değişiklik, devletin düzenleyici rolüne işaret etmekte, devlete atfedilen yeni rolün kurumsal çerçevesini işaret etmekte yani kısaca çok aktörlü yönetim modeli ve yeni kurumsal anlayışı somut hali olarak karşımıza çıkmaktadır.

Özellikle 1980'lerin başından itibaren tüm dünyada çok yönlü bir dönüşüm sürecine girilmiş, bu dönem neoliberalizmin birinci kuşak reformlarının dünya çapında uygulamaya geçtiği bir dönem olmuştur (Kalfa ve Ataay, 2008). Fordist üretim tarzından esnek üretim tarzına geçiş, bu döneme kadar var olan ulus devlet anlayışının sorgulanması ve yerini küresel dünyanın alması, ekonomik hayatta liberal yaklaşımın öne çıkması söz konusu olmuştur. Birey ile devlet arasında değişen ilişki ile birlikte "yönetim kavramı yerine yönetişim kavramı" (DPT, 2000) kullanılmaya başlanılmıştır. Yönetişim kavramı "governance" kelimesinden gelmekte olup; bire bir kelime anlamina baktı̆̆ımızda hükümet etmek, idare etmek olarak tanımlanabilir. 1980'li yıllardan itibaren yaygın olarak kullanılmaya başlayan yönetişim kavramı idareyi diğer aktörlerden, çıkar grupları, sivil toplum örgütlerinden ayrı tutmayan bir yaklaşım olarak karşımıza 
çıkar. Kjaer; yönetişimi kamu kesimini dışlamayan, ancak bunun yanında sivil toplumu, ortaklıkları ve piyasaları da yönetim işlevine içselleştiren bir yaklaşım olarak tanimlar (Kjaer, 2004).

\section{Bağımsız İdari Otoriteler}

Var olmuş idari yapılardan hemen hiçbirine benzemeyen bağımsız idari otoriteler için literatürde "üst kurular", "düzenleyici kurullar", "regülatörler", "regülasyon kurumları", "özerk kurumlar" gibi çok çeşitli adlandırmalar yapılmaktadır. Daha önce idari yapılanma içerisinde benzerlerinin olmaması, farklı statüde olmaları bu yapıların tanımlanması ve adlandırılmaları konusunda da sorunları beraberinde getirmektedir. "Devlet tüzel kişiliğinin çă̆daş yaşamın gelişmelerini kendi klasik erkleri (yasama, yürütme, yargi) eliyle karşılayamaz duruma gelmesi, klasik devlet yapısı içerisinde verilen hizmetlerde bürokrasinin ă̆ır ve hantal, ayrıca şeffaflıktan uzak işleyişi gibi nedenlerle, belli sektörlere göre etkinliklerin düzenlenmesi, denetlenmesi, bu düzenlemelere ilişkin kuralların yürütülmesi, siyasi müdahalelerden uzak, uzmanlık düzeyinde, donanımlı, bă̆ımsız, güvenli ve ayrı bir yapılanmayı gerekli kılmıştır" (Bahran, 2002) ve bu durum özerk yapıdaki kurumların yaygınlaşmasına neden olmuştur En genel tanım ile bağımsız idari otoriteleri stratejik öneme sahip olduğu düşünülen ekonomik sektörlerde düzenleme, denetleme ve yönlendirme faaliyetlerini yerine getirmek amacıyla, kanunla kurulan, idari ve mali özerkliğe sahip kamu tüzel kişileridir.

$\mathrm{Bu}$ noktada yönetişim kavramı ya da daha doğru bir ifadeyle kamu yönetiminde yönetişim anlayışı karşımıza çıkmaktadır. $\mathrm{Bu}$ yaklaşım kamu sektöründe etkinlik, verimlilik ve şeffaflı̆̆a vurgu yapan, kamu hizmetlerinin sunulmasının denetime açık olduğu, bu süreçlerde kamu sektörünün yanında vatandaşların, sivil toplumun ve özel sektör ajanlarının dahil edildiği, daha kuvvetli etkileşim a ğına dayanan bir sistemdir. Yönetişim; "yönetim masasında özel sektör ve şirketlere en güzel köşeyi ayıran, piyasaya duyarlı ve piyasadan beslenen bir yönetim anlayışı" (Zengin, 2009) olarak da tanımlanmaktadır. Elbette ki amaç kamu yararının arttırılması, kamu hizmetlerinin niceliklerinin yanında niteliklerinde de artışın sağlanmasıdır. Bu amaç doğrultusunda kamu kaynaklarının tahsisinden etkinliğin sağlanması, kaynakların tahsisi ile hedeflenen amaçlara uygun şekilde etkin, etkili, ekonomik kullanılması, idareler ve harcama birimlerine uygulamada daha fazla yetki verilmesi, bu konuda esnekliklerin sağlanması ve bunlara paralel olarak da hesap verilebilirlik ve saydamlı̆̆ın sağlanması için hareket edilmektedir.

Kamu işletmeciliğinin yasama gücünü de kullanabilmesi nedeniyle özel işletme gibi hareket etmesi istenmeyen bir durumdur (Lane, 2001). Önceki süreçte devletleştirilen alanlar, yeni dönemdeki liberalizasyon hareketleri çerçevesinde birer birer özelleştirilmeye başlanmıştır. Devletin tekelinde bulunan belirli alanların özel sektöre devri, özel tekellerin oluşması gibi bir durumu da ortaya çıkarmıştır. Bu tekellerin faaliyetlerini, uygulayacakları fiyatları kontrol etmek, piyasada rekabetçi ve etkin ortamı sağlamak adına da özelleştirme faaliyetlerine paralel olarak düzenleme faaliyetlerine girişilmesi gereği duyulmuştur. 1980'lerin başında özelleştirme dalgalarıyla gündeme gelen "Yeni Kamu Yönetimi stratejileri temelde işletme yönetimi ile kamu sektörü ve hizmetlerinin pazar ekonomisi koşullarına tabi kılınmasının bir bileşkesidir" (Uçkan, 2003). Bă̆ımsız idari otoriteler de bu noktada faaliyete geçmeye başlamışlardır. Özelleştirmelerin artışıyla eşanlı olarak oluşturulduklarını söylemek yanlış olmayacaktır.

\subsection{Bağımsız İdari Otoritelerin Ku- rulma Gerekçeleri}

Kamusal yaşamdaki belirli sektörlerin düzenlenmesi ve denetlenmesi, yine rekabete 
açılan hizmet sektörlerinde "işletme" ve "düzenleme" işlevlerinin ayrılması sonucu düzenleme işlevini yerine getirecek bağımsız otoriteye duyulan ihtiyaç (Kestane, 2002) klasik idari kuruluşlardan farklı yeni bir idari yapılanma modelini gerekli kılmıştır. 1981 yılında SPK'nın kurulması ile ilk olarak idari yapılanmamı içerisinde yer edinmeye başlayan ve yapılanmamız açısından yeni bir oluşum olan bağımsız idari otoriteler özellikle 1999 yılı sonrasinda devletin düzenleyici rolü çerçevesinde yaygınlaşmaya başlamıştır.

Çok çeşitli nedenle idari yapılanmalar içerisinde yer edinen bu yapılar farklı amaçlar ile farklı faaliyet alanlarına yönelmektedirler. Bağımsız idari otoriteler ilk olarak temel hak ve hürriyetlerin korunması, teminat altına alınmasının sağlanmasını kapsayan bir görevle yapılanma içerisine dahil olmuslardır. Bu anlamda "bağımsız idari otoriteler, idare ile göbek bağı kesilmiş yapılar olarak demokratik kuralların uygulanmasinda bireylere, güvenceler sağlamaktadırlar" (Atay, 2006). Ülkemiz açısından baktığımızda bu özellikteki bağımsız idari otoritelere RTÜK örneğini vermek doğru olacaktır. İkinci olarak bu otoriteler bireyle devlet arasındaki ilişkilerin iyileştirilmesi, geliştirilmesi noktasında görevler üstlenebilir ve mevcut sorunlarm minimuma indirilmesi noktasında görev alabilirler. Ancak üçüncü ve esaslı faaliyet alanları ise serbest piyasa düzeninin sağlanması, rekabetçi ortamın yaratılmasıdır. Piyasaların Pareto etkinlikten uzaklaşmasına neden olan piyasa başarısızlıkları bu noktada göz ardı edilmemelidir. Asimetrik bilgilenme, dısssallıklar, eksik rekabet koşulları rekabetçi, serbest piyasa düzeninin oluşmasının önünde engel teşkil etmektedir. Ülkemizde mevcut bağımsız idari otoriteleri daha çok bu kategoride değerlendirebiliriz (SPK, BDDK, EPDK, KİK.).

Kamu hizmeti tanımınin geleneksel anlamında uzaklaşması ile birlikte genel olarak ekonomik düzenlemelere ihtiyaç artmış, özel sektör hâkimiyetinin arttı̆̆g piyasa düze- ninde halkın bireysel çıkarlarının korunması önemli bir husus haline gelmiştir. Bu noktada ihtiyaç duyulan ekonomik düzenlemeler de artar hale gelmiştir. Kamunun piyasadan elini çekmesi üzerine rekabeti olumsuz etkileyici gelişmelerin yaşanmaması, daha öncesinde kamunun tekelinde bulunan çeşitli sektörlerde özel tekellerin oluşmasının önlenmesi, piyasa düzeninin etkin olarak işleyebilmesinin sağlanması için kurulan bu bağımsız idari otoritelere önemli roller düşmüştür. Ayrıca bu dönemde teknolojik gelişmelerde yaşanan artış da çeşitli alanlarda klasik idari yapılanmalar tarafından idare edilmesinde zafiyet riski ortaya çıkarmıştır.

"Her ne kadar bağımsız düzenleyiciler uzun süredir var olsalar da, bu organizasyonel modelin diğer düzenleme alanları ile uyum sağlaması 1980'lerin ortaları itibariyle olmuştur. Bu dönemde yaşanan reform sürecinden pek çok kurum nasibini almış; onların da bağımsızlıkları genişletilmiştir. Ancak her ne kadar eski bir oluşum olsa da; 1980'lerden önce kurulanlara kıyasla bu dönemde kurulan otoriteler sosyal düzenlemeden çok ekonomik düzenlemeye ilişkin olmaları bağlamında farklılık göstermektedirler" (Gilardi, 2005). Ülkemizde oluşturulan bağımsız idari otoriteler de bu dönem sonrasında vücuda gelmiş ve daha çok ekonomik alanın düzenlenmesi çabası sonucu oluşturulmuşlardır. Çeşitli ekonomik amaçlarla kurulduğu söylenen bu kurumlarm oluşturulmasında liberalleşme sürecinde önde yer alan ve bu sürece yön veren IMF ve DB gibi kurumlarm özelleştirme kapsamındaki çabalarının etkileri de yadsınamaz bir gerçektir. Bu yapılanmaların ülkemizde yer edinmesinin iradeye dayalı olarak, ülkenin içsel dinamikleri ile uyumlu bir şekilde oluşturulduğunu söylemek çok da mümkün görünmemekte olup; bu kurumlar kaynağını dış dinamiklerden alan yapılanmalar olarak karşımıza çikmaktadırlar.

Bayramoğlu'na göre ekonomik olan ile politik olanın ayrı olması gerektiğini öngörenler, 
politikayı bir hastalık olarak nitelendirmekte, politikanın ekonomiye etkisi olması durumunda bu hastalığı ekonomiye de bulaştırdı ̆̆ını düşünmektedirler ve bu durum da etkinsiz kaynak kullanımına ve ekonomik krizlere neden olmaktadır. Bağımsız idari otoritelerin oluşum sürecinde de bu düşüncenin etkin olduğu vurgulanmaktadır (Bayramoğlu Özuğurlu, 2005b). Dünya Bankası da ekonomik kalkınma açısından yaşanılan başarısızlıkların nedeni olarak devleti işaret etmiştir. Raporlarda minimal devletin öngörülmesi yerine, devlete farklı bir rol verilmiş, piyasanın etkinliği ön planda tutularak, piyasanın etkinliğinin sağlanabilmesi için devletin piyasaya müdahalesine ilişkin yeni düzenlemeler öngörülmüştür. Neoliberal yaklaşımın öngördüğü çok aktörlü yönetim yaklaşımı, piyasa-devlet-sivil toplum örgütlerinin birlikteliğine dayalı bir anlayış öngörülmüştür. Piyasaların belirleyiciliği temel alınmış, etkin piyasa yapılarının oluşturulması için de bağımsız idari otoriteler önemli rol üstlenmişlerdir.

\subsection{Bağımsız İdari Otoritelere İlişkin Görüsler}

Özeleştirmeler yapılması ile daha önce devlet eliyle yürütülen faaliyetlerin piyasa ekonomisine birakılması sonucunda bu yeni yapılanmalara ihtiyaç duyulmuş ve piyasa ekonomisine birakılan faaliyetlerin düzenlenmesi işlevinin devlet tarafindan yapılması gereği düşüncesi sonucu faaliyete geçirilmişlerdir. "Bağımsız idari otoritelerin ortaya çıkması ve gelişimi ile özelleştirme uygulamalarının başlaması ve devletçi politikaların yerine düzenlenmiş piyasa ekonomisinin uygulanmaya başlaması zaman açısından paralellik göstermektedir" (Bahran, 2002). Bu itibarla "özelleştirme olgusunun boş bıraktığı alanların bağımsız idari otoriteler tarafindan doldurulduğunu" (Kestane, 2002) söylemek gerekir.

Diğer ülkelerde çok çeşitli gerekçelerle kurulmuş olan bağımsız idari otoriteler; ülkemizde daha çok ekonomik alanda düzenleme yapılması amacı ile ortaya çıkmıştır. Devletin oluşan düzenlemeci yapısı gereği düzenleme, denetim ve gözetim işlevlerini yerine getirebilmesi için çok aktörlü yönetim yapısı oluşturulmaya çalışılmıştır. Bağımsız idari otoriteler; siyasi otorite ile idarenin birbirleriyle olan bağlarmı koparmakta olup, bu kurumların sektörlerdeki siyasi etkilenin minimuma indirilmesini, sektörlerde keyfilikten uzak ve objektif düzenleme yapılmasını sağlayacağı düşünülmektedir. Ayrıca düzenleyici devlet, var oluş amacı gereği ekonomik aktörlere eşit mesafede durmalıdır. Yeni yapılanma bürokrasinin etkisinden uzak hareket edeceği ve siyasi karar alma mekanizması ile birlikte işlemeyeceği için de bu yapıya uygun görülmektedir. Bu kurumlar özel öneme sahip sektörlere ilişkin oluşturulmaktadırlar ve bu sektörlerin idarenin keyfi düzenlemelerinden korunmasinın sağlanacağı, objektif olarak yönlendirileceği düşünülmektedir.

Her ekonomik aktör doğası gereği bireysel ve tekil çıkarlarının peşinden koşmaktadır. Doğal olarak ekonomik aktörler olan politikacılar da bireysel çıkarlarını düşünecek, rant kollamaya çalışacaklardır. Özel öneme sahip sektörlerde getiri maksimizasyonu peşinde olan bürokratların söz sahibi olması toplumsal fayda açısından olumsuzluklar doğuracaktır. Bu idareler sayesinde, sektörlere ilişkin kararlar daha bağımsız biçimde, ilgili konuda uzmanlaşmış kişilerce alınacak, sektörler daha objektif işleyişe sahip hale gelip, işlerlik kazanabilecektir. Bu kurumlar bankacilık, enerji, telekomünikasyon, medya, gibi hassas sektörlerdeki her durumun "hem çıkar gruplarının hem de politikacılarm müdahalelerinden ve ihlallerinden korunmasina hizmet etme misyonuyla" (Ulusoy, 1999) ortaya çıkarılmışlardır. Batı Avrupa'da da bu kurumlar, enerji, telekomünikasyon, sermaye piyasaları, çevre, posta hizmetleri, sağlık gibi ülkemizdekine benzer alanlarda yetkili olarak kurulmuslardır (Thatcher, 2002).

Piyasada aktör olarak yer alan devletin 
aynı zamanda piyasayı düzenlemesi haksız rekabete yol açacaktır ve bu durumda devlet eliyle alınan kararların objektifliği hususunda soru işaretleri oluşacaktır. Devletin sektörde hem aktif rol alması hem de sektörün düzenleyicisi olmasmın neden olduğu aşırı yetkililik halini giderme noktasında düzenleyici kurumlara gereksinim artmaktadır (Majone, 1996). Bu bağımsız kurumların varlığı haksız rekabete engel teşkil edecek ve tarafsızlı̆̆ın sağlanmasını temin edilecektir. Ayrıca seçilmiş sektörlere yönelik oluşturulmuş olan sektörlerin düzenlenmesinde siyasi kişiliklerden öte, bu alanda uzmanlaşmıs, teknik bilgiye sahip kişilerin görev alması daha uygun olacaktır. $\mathrm{Bu}$ özerk yapıların oluşturulmasıyla birlikte ilgili sektörlerde uzman görüşünün hakim olacağ1 ve sektörlerde işleyişin, kamusal düzenlemeye kıyasla, daha etkin ve verimli olacă̆1 düşünülmektedir. Duran (1997), bağımsız idari otorite modelinin yeni teknoloji, mali enstrüman ve manipülasyonların bazı temel hak ve özgürlükler ile ekonomik düzeni tehdit ve ihlallere karşı kollama misyonunu yerine getireceğini ve bu amaç ile oluşturulduklarını dile getirmektedir. Bă̆ımsız idari otoritelerin varlığı bu tür ani politika değişiklikleri ile piyasayı ani ve suni değiştirme serbestîsini de ortadan kaldırmaktadır.

Geleneksel bürokratik kurumlardan farklı yapılanmaya sahip olan bu kurumların idarenin bütünlüğü ilkesine dayalı olarak oluşturulan kamu kurumları dışında oluşturulmaları ile devletin tüzel kişiliğinin parçalandığı üzerinde durulmakta; ayrıca kamu yönetimindeki parçalanmanın yanında bu kurumların oluşturulmalarının ekonomi yönetimi açısından da çok başlılık yaratacağı, bütüncül yapıya zarar verebileceği, ekonomik kalkınma yönünde etkin politikaların oluşturulması önünde engel teşkil edeceği yönünde görüşler de bulunmaktadır. Hızla artan kurumların arasında koordinasyonu sağlayacak bir birim ya da kurumun yokluğunun da piyasalar açısından sıkıntı yaratabilecĕ̆ine değerlendirilmektedir.

\section{3 Ülke Karşılaştırması}

\subsubsection{Amerika Birleşik Devletleri (ABD)}

Bağımsız idari otorite yapılanmasinın ilk ortaya çıktığı ülke ABD olmuştur. Ülkemizde olduğu gibi ABD'de de bu kurumlar çok çeşitli adlarla anılmaktadırlar. Hem federal düzeyde kurulan ilk otorite, hem de ABD'de ilk kurulan bă̆ımsız idari otorite, devletlerarası ticari işlemleri düzenlemek için kongre tarafından oluşturulan (Eyaletlerarası Ticaret Komisyonu) Interstate Commerce Commision (ICC)'dır. Bir ilk niteliğinde olan bu kurum 1995 yılında kaldırılmıştır.

Amerikan sisteminde özel sektörün öncü olması hususunda rahatsızlı duyulmamakta olup; piyasa sisteminin normal işleyişine bırakıldığında bazı özel durumlar dışında iyi işlediği, dolayısıyla bu özel durumlar dışında da piyasanın doğal işleyişine müdahale edilmemesi gerektiği fikri hakimdir. Bu düşünce sistemi ekseninde oluşturulmuş bă̆ımsız idari otoritelerin kurulma gerekçeleri, tüm ülkeyi ilgilendiren, özellikle de ekonomik konularda çok başlılığı önleyip, federal düzeyde bir örgüt yaratmak ve bunun yanında parlamentonun ve başkanın ekonomik konulara ilişkin görev ve yetkilerini sınırlamak olarak gösterilebilir. "Ayrıca serbest piyasa her ne kadar kaynak tahsisi ve tüketicinin refahının maksimize edilmesi açısından en etkin yol olsa da, piyasadaki aktörlerin optimum kaynak dağılımını sağlamakta eksikliklerinin olabileceği düşüncesinden ortaya çıkmaktadır" (Bertozzi ve Burgunder, 1990). 1929 Dünya Ekonomik Bunalımı döneminde, serbest piyasa fikrinin zarar görmesi ile var olan müdahale karşıtı yaklaşım yerini müdahaleyi öngören Keynesyen yaklaşıma bırakmıştır. Bu dönemde Avrupa ülkeleri tarafindan devletleştirme politikalarına doğru bir yönelim görülmüştür. ABD'de ise bunun aksine bağımsız idari otoriteler aracılı̆̆ıla piyasayı düzenleme yolu tercih edilmiş, bu dönemde otoritelerin sayıları yanında yetki ve sorumlulukları da arttırılmıştır. 
$\mathrm{Bu}$ dönemde 1930 yılında Federal Enerji Komisyonu, 1934 yılında Federal İletişim Komisyonu, 1934 yılında Menkul Kiymetler ve Borsa Komisyonu, 1935'te Ulusal Çalışma İlkeleri Komisyonu ve 1938 'de de Sivil Havacılık Kurulu oluşturulmuştur. 1929 ekonomik bunalımı ile ülkede önemi artan bağımsız idari otoriteler 2. Dünya Savaşı ardından kendilerine verilen eski değeri yitirmiş, ancak 1980'li yıllara gelindiğinde diğer ülkelerde gündeme gelmesi ile birlikte yeniden ön plana çıkmış ve sayıları artmaya başlamıştır.

Bugün hemen her konuda ve oldukça fazla sayıda bağımsız idari otoritesi bulunan ülkede bu kurumlarm kurulmaları ABD kongresi tarafindan çıkarılan kanunla gerçekleşmektedir. Bütçelerinin belirlenmesi ve denetlenmeleri de yine kongre tarafından gerçekleştirilmektedir. Kurumların bütçelerinin denetimi de başkana bağlı bulunan bir birim tarafindan yerine getirilmektedir. Ülkemizde de olduğu gibi bu otoritelerin karar mercii olan bir kurul yapılanmaları söz konusudur ve kurul üyeleri başkan tarafindan atanmaktadırlar. Başkan tarafından seçilen bu üyelerin genellikle siyasetten bağımsız olmaları tercih edilmektedir. Başkan tarafından atanmış üyelerin görev süreleri dolmadan önce görevden alınmaları, bağımsızlıklarını temin etmek adına, uygun görünmemektedir.

Bağımsızlık temelinde oluşturulmuş bu kurumların üzerinde yasama, yürütme ya da yarginın herhangi bir etkisi söz konusu değildir. $\mathrm{Bu}$ kurumlar kanunla kendilerine tanınmış alan çerçevesinde düzenleme yapmaktadırlar. Kurumların bağımsızlıklarına gölge düşürebilecek bir husus Kongrenin dilediği zaman çıkaracağ $\breve{~ b i r ~ k a n u n l a ~ k u-~}$ rumun kararlarını etkisiz kılabilecek olması ve yine çıkarılacak bir kanun ile kurumların görev ve yetkilerinde istenen değişikliğin yapılabilecek olmasıdır.

$\mathrm{Bu}$ kurumların dikkat çeken bir diğer özelliği de bir yargı organı gibi konuları değerlendirebilmeleri, idari hakim istihdam edebilmeleri ve gerekirse duruşma yapabil- meleridir. "Koydukları kural ve yaptıkları düzenlemelere uyulmadığı takdirde, adeta bir mahkeme gibi, soruşturma yapıp ceza verebilmeleri bakımından, bağımsız idari otoritelerin ABD'de yargı gücü kullanan uzman mahkeme gibi çalıştıkları söylenmektedir" (Emek, 2002). Bu kurumlarm yasama organı olarak $\mathrm{ml}$, yürütme organı olarak mı, yoksa yargı organı olarak mı değerlendirilecekleri hususu da tıpkı ülkemizdeki gibi net değildir. Ülkedeki bağımsız idari otoriteler mevcut yapı dışında ayrı bir konuma sahiptirler, bakanlık hiyerarşisinde de yer almamaktadırlar.

ABD'deki bağımsız idari otoritelere ilişkin dikkat çeken bir diğer özellik de ABD Anayasası'nda yer almamaları, anayasada bu kurumlara ilişkin bir düzenlemenin yer almamasıdır. Yüzyılı aşkın süredir ABD'de varlığını sürdüren bu kurumların hala anayasal dayanaklarının bulunmaması ilginç bir durumdur. Sonuç olarak her ne kadar anayasal dayanakları olmasa da, ABD idari yapılanmasında bağımsız idari otoriteler önemli roller üstlenen kurumlardır ve yasama, yürütme, yargı erkleri yanında dördüncü erk olarak da nitelendirildikleri olmaktadır.

\subsection{2 İngiltere}

Tarihi açıdan bakıldığında ABD'de bağımsız idari otoritelerin yüz yılı aşkın süredir idari yapılanmada yer almalarına rağmen, İngiltere'deki bağımsız idari otoriteler daha ön plana çıkmıs, rol model olarak benimsenmişlerdir. Bunun nedeni esasen 1980'li yıllarla birlikte oluşan düzenleyici devlet anlayışına çerçevesinde, bu dönemdeki neoliberal politikalarm ürünü olarak ortaya çıkmış olmalarıdır. "Ingiltere'nin bağımsız idari otoritelerin yurdu olarak kabul edilmesi; devletin sosyal ve ekonomik işlevlerinin budanması ve ekonominin siyasetten arındirılması programını ilk uygulayan ülke olmasıyla ilgilidir" (Bayramoğlu Özuğurlu, 2005b). Diğer Avrupa ülkelerinde de olduğu gibi 
bir dönemde İngiltere'de de millileştirme hareketleri, diğer ülkelerdekine benzer gerekçelerle, düzenlemenin temel yöntemi olarak benimsenmiştir (James, 2005). Ancak zamanla ülkedeki düzenleme kapasitesinin arttırılmasından beklenen bu hareketlerin hiç de bu yönde bir etki oluşturmadığı anlaşılmış ve bununla birlikte de bu durumdan uzaklaşılmaya başlanmıştır. Millileştirme hareketleri ekonomik düzenlemeler açısından beklenen gelişmeleri sağlayamamasının yanında sosyo-politik açılardan da başarısız olmuştur (Majone, 1996). Avrupa'da çok çeşitli gerekçelerle öne çıkarılan millileştirme, devletleştirme uygulamaları, iktisadi bakış açısındaki ve bununla beraber toplumsal yapıdaki güç dengelerindeki değişim süreci ile arka plana atılmış ve bu noktada da özelleştirme hareketleri gündeme taşınmıştır.

İngiltere'de bağımsiz idari otoriteler ile özelleştirme uygulamaları birbirlerine paralel bir seyir izlemişlerdir. İngiltere'de özelleştirme süreci 1984 yllında British Telecom'un özelleştirilmesi ile başlar. Bu ilk büyük özelleştirmeyi 1986 yılında yapılan British Gas'ın özelleştirilmesi izler. Telefon ve gaz hizmetlerinde özelleştirmeleri elektrik ve su hizmetleri takip etmiştir. 1989 yılına gelindiğinde kamu sektörünün \%25'inden fazlası özel sektöre devredilmiş ve yapılan özelleştirmeler sonrasında da, özelleştirilen sektörlerin düzenlenmesine yönelik olarak bazı yasal ve kurumsal düzenlemeler gerçekleştirilmek durumunda kalınmıştır (Karasu, 2004). Bu yönde atılan ilk adım, özelleştirilen sektörlere yönelik düzenleyici kurumlar oluşturulması yönündedir. Ülkede oluşturulan bu kurumlar hükümetten bă̆ımsız, klasik bakanlık yapılarının dışında fakat hükümetin işlevlerini yerine getiren özerk kurulları ifade etmektedir (Syrett, 2003). 1980'lerde bu amaca hizmet etmek adına yaklaşı on adet otorite oluşturulmuştur. Bunlardan başlıcalarI 1984 yılında kurulan telekomünikasyon sektörü düzenleyicisi OFTEL, 1991 yılında kurulan Su hizmetlerine ilişkin düzenleyici
OFWAT, 1999 yllında kurulan Gaz ve Elektrik Piyasaları Düzenleyicisi OFGEM, 1993 yılında kurulan Demiryolları ORR'dir (OECD, 2002). İngiliz Hükümeti 2000 yılında yaptırdığ olarak, elektrik ve doğalgaz sektörlerini birleştirerek yeni ve değişik bir yapı altında her iki sektörü de oluşturulan bağımsız kuruma bağlanmıştır (Thomas, 2001).

İngiltere'deki bağımsız idari otoritelerin birbirlerinden farklılaştıkları görülmektedir. Kurul başkan ve üyeleri genel olarak ilgili bakanlık tarafından atanmaktadır. Hükümet tarafından yapılan atama siyasi etkilerden uzak durulabilmesi hususunda soru işaretleri oluşturmaktadır. İlgili bakan tarafindan atanan kurul başkanı, aynı şekilde ilgili bakan tarafından, her ne kadar çok istisnai durumlarda olsa da, görevinden alınabilmektedir. Ayrica bunun yanında tarafsılılı açısından önemli bir soru işareti oluşturabilecek olan, kurul başkanının kamuda başka görev alamaması yasağı da söz konusu değildir. Ancak başkan, tarafsızlığının temini için var olan diğer ortaklıklarından feragat etmek zorundadır. Yine de ülkemizle kıyasladığımızda tarafsız, etki altında kalmadan karar alınabilmesini sağlayacak bazı güvencelerin yoksunluğu dikkat çekmektedir.

Ülkedeki bağımsız idari otoriteler genel bütçe dışında tutulan kendilerine özgü bütçeye sahiptirler. Ayrıca ilgili kanunla kendilerine verilmiş olan görev ve yetkileri yerine getirirken de özerk bir yapıya sahiptirler. İngiltere'deki otoriteler lisans verme, öneride bulunma, düzenleme yapma, denetim yapma gibi hizmetleri yerine getirmektedirler. Ayrıca bilgi amaçlı olarak parlamento ve hükümete düzenli olarak raporlar sunmaktadırlar. "İngiliz bağımsız idari otoriteleri, parlamentonun genel gözetimi, Ulusal Denetleme Kurulu ve Sayıştay'ın denetim ve gözetimi ile idari ve mali konularda hesap verme yükümlülüklerini yerine getirmektedirler" (Kaya, 2004). 


\subsubsection{Fransa}

Fransa'da ilk bağımsız idari otoriteler 1941 yılında kurulan, 1984 yılında kaldırılan Bankalar Denetim Komisyonu'dur. 1970'li yıllardan itibaren Fransa'da da bă̆ımsız idari otoriteler idari örgütlenme içerisinde yaygın olarak yer almaya başlamışlardır. Esasen Fransız hukuk geleneğinde bağımsız idari otoriteler yer almazken; diğer ülkelerdeki uygulamalardan etkilenerek bu uygulamaları sisteme dahil edilmiş ve kendi sistemi içerisinde de bu kurumlara özgünlük kazandırılmıştır (Morange, 1998). Merkezi bir yapılanmaya sahip olan ülkede zamanla teknik özelliklerin artması ile birlikte uygulanmakta olan denetim ve gözetim usullerinin yetersizliği gözler önüne serilmiş ve bu yetersizliği giderme yöntemi olarak bağımsız idari otoriteler görülmüştür. Ülkedeki var olan katı hiyerarşi bu noktada önemli sorunlar doğurmuştur. Ancak mevcut kurumlardan farklı yapısal nitelikte olan otoriteler, sistem içine kanalize edilmiştir. Her ne kadar dönem içerisinde görülen yetki ve sorumluluğun dağıtılması (decentralisation) çabaları da bă̆ımsız idari otoritelerin oldukça yabancı oldukları Fransiz idari yapılanmasina entegre olmalarını kolaylaştıran bir etmen olsa da; yine de bu süreç kolay olmamış, beraberinde sancılar getirmiştir.

"Anglo-sakson sisteminin "agency" modeline benzeyen bağımsız idari otoritelerin kendilerine özgü tüzel kişilikleri yoktur. Merkezi idarenin veya yetki genişliği idarelerinin klasik yapıları içinde yer almadıkları gibi, genel olarak idari hiyerarşi içinde de yer almazlar" (Karahanoğulları, 2004). "Fransa'daki bağımsız idari otoriteler, yasa koyucu tarafindan oluşturulan, geleneksel idari yapının dışında konumlandırılan, bă̆ımsızlık garantileri verilen ve belirli sektörlerde düzenleme ve müdahale yetkileri bulunan otoriteler olarak tanımlanmaktadır" (Yılmaz, 2005). Ülkede oluşturulan bă̆ımsız idari otoritelerin tüzel kişilikten yoksun olarak oluşturulmuş olmaları dikkat çeken bir özelliktir. Tüzel kişilikten yoksunluk bağımsızlık açısından soru işareti olarak görülebilse de, otoriteler kuruluş mevzuatlarına dayalı olarak organik bă̆ımsızlı̆̆a sahiptirler. "Üyelerinin yüksek yargı yerleri, cumhurbaşkanı ya da Millet Meclisi Başkanı tarafindan atanması, üyelere azledilemezlik gibi organik güvenceler sağlanması bu bağıımsızlı̆̆ın bir göstergesidir" (Yılmaz, 2005). Ayrica bu otoriteler üzerinde herhangi bir idari hiyerarşi olmadığı gibi, idari vesayete de tabi değildirler.

Organik bă̆ımsızlı̆̆ın yanında, fonksiyonel bă̆ımsılık da elbette ki önem arz etmektedir. Fonksiyonel bă̆ımsızlı̆̆ın ilk işareti bütçe, harcama serbestisi olarak karşımıza çıkmaktadır. Ancak Fransa da bu kurumlar bütçelerini kendileri oluşturamamaktadırlar. Organik bă̆ımsızlık açısından serbesti sağlanmış olsa da fonksiyonel bağımsızlığın tam anlamıyla varlığı soru işaretleri oluşturmaktadır. $\mathrm{Bu}$ durum her ne kadar bağımsız olmadıklarını işaret etmese de bağımsızlıklarına gölge düşüren bir unsur olarak görülebilmektedir. Otoriteler üzerinde kısmen parlamento denetimi de bulunmaktadır. Çeşitli şekillerde denetim mekanizması kullanılmaktadır. (Üyelerin atanması, sözlü yazılı soru, bütçe görüşmeleri...) Aynı zamanda otoriteler parlamento ve hükümete bilgi amaçlı rapor sunmaktadirlar.

Fransa'daki bağımsız idari otoriteler kendilerine verilmiş olan görevleri yerine getirebilmek adına güçlü kamusal yetkilerle donatılmışlardır. Ülkedeki otoritelerin görev ve yetkileri diğer ülkelerle benzer şekilde, düzenleme yapma, görüş bildirme, öneride bulunma, yaptırım uygulama, araştırma ve soruşturma yapma olarak sayılabilir. Otoriteler tarafından verilmiş kararlara karşı idari yargı mercilerinde dava açılabilir. Dava sonucunda otoritelerin kusur, ihmallerinin söz konusu olduğu kararı ortaya çıkarsa, bu durumda tüzel kişilikten yoksun olmaları nedeniyle sorumluluk devlet tarafindan üstlenilecektir. 


\subsubsection{Avrupa Birliği}

Uluslararası kuruluşların bağımsız idari otoritelerin yapilanması konusunda israrc1 tutumları söz konusu olmuştur. Düzenleyici devlet yapısı kapitalist ekonominin dönüşümü ile ortaya çıımış bir yapı (Jordana ve Levi-Faur, 2004) olarak düşünülmelidir. $\mathrm{ABD}$ ve İngiltere'nin ardından küreselleşmenin etkisi ile yeni düzenleyici devlet yapısı oluşturulması çerçevesinde $\mathrm{AB}$ üyesi ülkelerde de bağımsız idari otoriteler ortaya çıkmaya başlamıştır. Bu ülkelerde bağımsız idari otorite yapılanmasına gidilmesinin bir nedeni de aslında ABD ve İngiltere'de başvurulmuş olan otoritelerin piyasa açısından olumlu değerlendirilmesi sonucunda kendi ülkelerinde de uygulama istekleridir. Ancak "AB ülkelerindeki düzenleyici kurum örneklerine bakıldığında, bu ülkelerin kamu yönetimi gelenekleri ile hukuk sistemlerinin ABD ve İngiltere'den farklı olmasının izdüşümü kolayca fark edilmektedir" (Acar vd., 2002).

1970'lerin sonundan kendini gösteren küreselleşme ile birlikte AB üyesi ülkeler arasında hızlı bir bütünleşme süreci yaşanmıştır. Bu çerçevede de bağımsız idari otoriteler oluşturulmaya başlanmıştır. Esasen AB'de bağımsız idari otoritelerin oluşumunun tam olarak da müdahaleci devletten düzenleyici devlete geçis esnasında olduğunu söylemek yanlış olmayacaktır.

$\mathrm{AB}$ içerisinde oluşturulmuş olan bağımsız idari otoriteler bağımsız kamu kurumları olarak oluşturulmuşlardır. Farklı zamanlarda ve farklı ihtiyaçlara cevap vermek adına oluşturulmaları nedeniyle mevcut bağımsız idari otoritelerin özellikleri arasında önemli farklılıklar gözlemlenebilmektedir. $\mathrm{Bu}$ otoriteler Avrupa Konseyi tarafindan çıkarılan mevzuatla, bağımsız, ayrı tüzel kişiliğe sahip kamu kurumları olarak kurulmuşlardır. Diğer örneklerdekine benzer olarak daha çok piyasa açısından önem arz eden, teknik uzmanlık gerektiren alanlarda oluşturulmuşlardır. Kurulan alanlar yanında kuruluş gerekçelerinde de benzerlikler söz konusudur. Bağımsız idari otoriteler mevcut bürokratik yapının hantal işleyişinden kurtularak daha etkin, hızlı bir yapının oluşturulması amacına hizmet etmektedir. AB'nin yapısı gereği var olan merkezi bürokratik yapı üye ülkelerin yönetime katılmaları hususunda da sikıntılar getirebilmektedir. Oluşturulan bağımsız idari otoriteler ile hem bu bürokratik yapı kırılmış olacak; hem de üye ülkelerin ihtiyaçlarına cevap verebilecek mekanizmalar oluşturulmuş olacaktı.

\section{Türkiye}

Önceleri ABD ve Kita Avrupa'sinda örnekleri bulunan bağımsız idari otoriteler, 1980'lerdeki küreselleşme rüzgârının da etkisiyle ülkemizde de yer edinmeye başlamışlardır. $\mathrm{Bu}$ yapılanma mevcut idari yapılanmadan farklı nitelikte, yeni yapılanmalar olarak idari örgütlenmeye dahil olmuşlardır.

Türkiye'de 1980'li yıllarda ekonomik yapı yeni bir çehre kazanmıştır ve bu yenilikler idari yapılanmayı da paralel olarak etkilemiştir. "Liberal ve dişa açık ekonomik yapı ve AB'ye tam üyelik yolunda atılan adımlarla birlikte bağımsız idari otoritelere ilişkin olarak dış ülkelerde uzun süredir gözlemlenen hareketlilik, zorunlu olarak ülkemize de yansımış ve bağımsız idari otoriteler kurulmaya başlanmıştır" (Bayramoğlu Özuğurlu, 2005a). Bağımsız idari otoritelerin oluşumu konusunda dönüm noktasını 24 Ocak 1980 kararları olarak işaret etmek yanlış olamayacaktır. Liberal ekonomik yapının oluşturulması, devletin üretici kimliğinden siyrılıp, düzenleyici kimliğine bürünmesi sürecinde bu kurumlar idari yapılanma içerisinde yer edinmeye başlamışlardır. Bu kurumlar bağımsız nitelikte, idari ve mali özerkliğe sahip olarak ülke dışında yaşanan gelişmelerin paralelinde ülke düzeninde yer edinmişlerdir.

1980 yılındaki 24 Ocak kararları ülkede yaşanan dönüşümün bir göstergesidir. 24 Ocak 1980 kararları ile birlikte ülkede bugüne kadar var olan anlayış terk edilmiş, farklı bir yapılanma yolunda politika- 
lar oluşturulmaya, adımlar atılmaya başlanmıştır. Kalkınma için bu döneme kadar uygulananlardan bambaşka politikalara geçilmiştir. Bu politikaların ana belirleyicisi liberalleşme, uluslararası ticarette entegrasyon ve ihracata dayalı büyümedir (Sezen, 2002). Devletin ekonomiye müdahalesi minimuma indirilecek, rekabeti engelleyici kısıtlamalar kaldırılacak ve uluslararası piyasalarla bütünleşme sağlanacaktır. 24 Ocak Kararları denen bu program, dünya piyasaları ile bütünleşmeyi sağlamak için çalışan, ülke ihracatını arttırma yönünde çabaları öne çıkaran bir dışa açılma stratejisidir denebilir. Bu kararlar ile birlikte "serbest" piyasa ekonomisine geçiş doğrultusunda kamu kesiminden özel kesime kayış görülmüştür. "24 Ocak kararları ile başlayan dönüşüm sürecinde, "daha az devlet, daha çok piyasa" ilkesine dayanan ve giderek derinleşen liberalleşme politikalarını, devlet örgütlenmesindeki en önemli izdüşümleri bağımsız idari otoriteler olmuştur" (Sezen, 2003).

Kısacası görüldüğü gibi 1970'lerden itibaren tüm dünyayı etkileyen akımlar gecikmeli olarak da olsa Türkiye'yi de etkisi altına almış ve 1980 'ler itibariyle yayılan bu anlayışa uygun politikalar oluşturulmuştur. 1989 yılı itibariyle de sermayenin serbest dolaşımı büyük oranda sağlanmıştır. 1990'lı yıllar ve sonrasında bu politikalar doğrultusunda, birçok KİT özelleştirilmiştir.

"Devletin iktisadi ve toplumsal hayata doğrudan müdahalesi sinırlandırılarak, düzenleyici rolünün ön plana çıkmasıyla Türk kamu yönetiminde yeni yapılanmalar da ortaya çıkmaya başlamış, liberal dönemde var olan örgütlenmedeki "kurumlara dayalı yönetim" anlayışı yerini giderek "kurullara dayalı yönetim" anlayışına bırakmıştır. Devletin iktisadi ve toplumsal hayata doğrudan müdahalesi sinırlandırılarak, düzenleyici rolünün ön plana çıkmasıyla Türk Kamu Yönetiminde yeni örgütlenmeler ortaya çıkmaya başlamıştır" (Sezen, 2003). Türkiye'de bağımsız idari otoritelerin temeli tam da bu dönemde atılmıştır.

Türkiye'deki düzenleyici yapı 2000/2001 krizinin ardından önemli ölçüde gelişmiştir ve ayrıca kriz IMF, AB gibi dışsal aktörlerin elini önemli ölçüde güçlendirmiş, düzenleyici reformlar ile bu reformların uygulanması için gerekli kurumsal kapasitenin geliştirilmesi yönünde ülkeye baskı uygulamalarına neden olmuştur (Öniş ve Şenses, 2007).

\subsection{Türkiye'deki Bağımsız İdari Otori- telerin Gelişim Seyri}

1980 yılındaki 24 Ocak Kararları ile liberalleşme politikaları ülkemiz açısından ön plana çıkmıştır, bağımsız idari otoriteler de bu dönemdeki uygulanan politikalarm bir yansıması olarak karşımıza çıkmaktadırlar. Yaşanan küreselleşme dalgası ve liberal politikalara uyum sağlanmasının yanında, AB'ye uyum süreci, IMF ve DB'nin ülkemizden talepleri, yabancı finans kuruluşlarına bağımlılık gibi etmenler de bağımsız idari otoritelerin oluşumunu ve gelişimini önemli ölçüde etkilemiştir. "Belli başlı uluslararası kuruluşlar yönetişim kavramının ve modelinin düşünsel inşasında etkili olmuşlardır" (Bayramoğlu Özuğurlu, 2005b). AB, DB, IMF, OECD, ILO bu konuda öncü kuruluşlar olarak sayılabilir. Bu kuruluşlar yönetişim anlayışının inşasının yanında, uygulanması aşamasında da aktif roller üstlenmişlerdir. Yeni bir yapılanma olan bağımsız idari otoriteler aşamalı olarak Türk kamu yönetiminde yer edinmişlerdir. Her ne kadar başlangıç dönemlerinde hareketler az olsa da kayda değer gelişmeler kat edilmiş ve izleyen dönemlerde yapılanmalar yaygınlık kazanmıştır.

Ülkemizde bağımsız idari otoritelerin yer edinmeleri süreci üç döneme ayrılmaktadır. $\mathrm{Bu}$ dönemler ortaya çıkış, gelişme ve yaygınlaşma dönemi olup; bu dönemlere paralel olarak bağımsız idari otoriteler, birinci kuşak kurumlar, ikinci kuşak kurumlar, üçüncü kuşak kurumlar olarak sınıflandırılmaktadırlar. Birinci kuşak kurumlar ortaya çıkış döneminde, ikinci kuşak kurumlar gelişme döneminde ve üçüncü kuşak kurumlar da yayginlaşma 
döneminde ortaya çıkmıs kurumlardır. 1980'lerde iyice su yüzüne çıkan liberalleşme politikalarını idari yapılanmada ortaya çıkardığ 1 en önemli yenilik olarak bağımsız idari otoriteler 1981 yılında Sermaye Piyasası Kurulu'nun (SPK) oluşturulması ile Türk kamu yönetiminde yer edinmeye başlamıştır.. "SPK ile ülkemiz bağımsız idari otorite kavramı ile tanışmaya başlamıştır" (Kahraman, 2005). "SPK'nın kuruluşu, ülkede yaşanan banka ve banker skandallarının oluşturduğu zemin üzerine oturtularak, liberal iktisadi politikalarm ihtiyaç duyduğu kamusal örgütlenme modelini hayata geçirmiştir" (Eren, 2004). Sermaye Piyasası Kurulu'nun oluşumu bağımsız idari otoritelerin oluşumunda birinci kuşak olarak nitelendirilmektedir. 1982 yll itibariyle faaliyete geçmiş olan bu kurum ilk olmanın yanında aynı zamanda on yılı aşkın tek olma niteliğine de sahip olmuştur.

Bağımsız idari otoritelerin ikinci kuşağının oluşumu ise 1990'lı yılların ilk yarısında başlar. $\mathrm{Bu}$ dönemde oluşturulan bağımsız idari otoriteler Radyo ve Televizyon Üst Kurulu ile Rekabet Kurumu olmuştur. Radyo Televizyon Üst Kurulu, yaymcılık tekelinin hukuken kaldırılmasının arkasından, radyo ve televizyon yayıncıllğındaki serbestleşme hareketlerinin de bir sonucu olarak, radyo ve televizyon yayıncılığını düzenlemek ve denetlemekle görevlendirilmiştir. Kısacası "kurul, radyo ve televizyon yayıncılığı alanındaki liberalleşmenin bir ürünü" (Sezen, 2003) olarak ortaya çıkmıştır. Rekabet Kurumu da piyasa düzenindeki rekabet ortamın korumak ve denetlemek üzere kurulmuştur. Bağımsız idari otoritelerin üçüncü kuşağı olarak da adlandırılan otoritelerin yaygınlaşma dönemi ise 1999 yılı ve sonrasını kapsar. $\mathrm{Bu}$ dönemde 2001 yılında yaşanan ekonomik krizin ardından uygulamaya konan "Güçlü Ekonomiye Geçiş Programı" ile birlikte Türkiye'ye gelen Kemal Derviş "on beş günde on beş yasa" olarak nitelenen faaliyetler kapsamında bağımsız idari otoritelerin kurulmasinda etkin rol oynamıştır. Bayramoğlu, bu yasama faaliyetini, yönetişim modelinin inşa sürecinde demokratik ilkelerin ihlali olarak değerlendirmektedir (Bayramoğlu Özuğurlu, 2005b). Bu faaliyetler ekseninde, 1999 yılında Bankacılık Düzenleme ve Denetleme Kurulu, 2000 yllnda Telekomünikasyon Kurumu, 2001 yllında Enerji Piyasası Düzenleme Kurumu, Şeker Kurumu, 2002 yılında da Tütün, Tütün Mamulleri ve Alkollü İçkiler Piyasası Düzenleme Kurumu ve Kamu İhale Kurumu kurulmuştur. Bu beş kurum da, üçüncü kuşağı oluşturmaktadır 2000'li yılların başından itibaren sayıları giderek artan bağımsız idari otoriteler, 2002 yll sonrasinda durgun bir döneme girmişlerdir. Ancak yapılan son bir düzenleme ile 26/09/2011 tarih ve 660 sayll Kanun Hükmünde Kararname ile Kamu Gözetimi, Muhasebe ve Denetim Standartları Kurumu kurulmuştur. Bağımsız idari otoritelerin belirli bir dönemde sayıca bu denli hızlı fazla artış göstermesi bazı çevrelerce sıkıntılı bir süreç yaratabileceği kanısını oluşturmuştur. Otoriteler bir anda kanuni düzenleme yapılmak suretiyle, ülke içi etmenler yeterince hazır olmadan ve dikkate alınmadan oluşturulmuşlardır.

Ülkemizdeki bağımsız idari otoritelere baktığımız zaman açıkça görüldüğü gibi, birinci ve ikinci kuşak olarak değerlendirilen dönemde kurulmuş olan otoriteler genel düzenleyici nitelikte iken; 1999 yllinda BDDK'nın kurulması ve takip eden süreçte kurulan otoriteler piyasalara ilişkin oluşturulmuşlardır. Bu dönemde bağımsız idari otoriteler nicelik olarak artmalarını yanı sıra, yazılı ve görsel basında daha çok tartışlır ve kamuoyunda daha geniş bir kesim tarafından fark edilir hale gelmişlerdir (Sezen, 2003). Bu kurumlar oluşturulmalarından itibaren önemli bazı eleştiriler ile karşılaşmışlardır. Olağanın dışında bir kurumsal yapılanmaya sahip olan bu kurumların sayıca artışları, kendilerinden beklenen bağımsız düzenleyici niteliklerine ve diğer özelliklerine zarar verebilir nitelikte olabilecektir. Ulusoy (1999) da bu görüşü destekler şekilde, bu kurumlarm 
olağan yapılar olarak değil de istisnai yapılar olarak görülmesi gerektiğini ve buna bağlı olarak da sayılarının mümkün olduğunca düşük tutulması gerektiğini savunmaktadır. Yaygınlaşma dönemi bu kurumların daha çok göz önünde oldukları ve dolayısıyla daha çok eleştirilere maruz kaldıkları bir dönem olmuştur.

Türkiye için oluşturulan IMF destekli istikrar programlarında bağımsız idari otoritelerin oluşturulması ön koşullar arasında yer almaktadır. Bă̆ımsız idari otoritelerin kurulmasının gerekliliğine ilişsin taahhütler de niyet mektuplarında bulunmaktaydı. 1999 yll ve sonrasindaki Niyet Mektuplarında, Dünya Bankası ile yapılan ikraz antlaşmalarına bakıldığında bu kurumların oluşturulmaları konusu anlaşılabilecektir. BDDK, EPDK, KİK bu niyet mektupları çerçevesinde verilmiş taahhütler olarak karşımıza çıkmaktadırlar. "Yapısal uyarlama kredilerinin ise bağımsız idari otoritelerin oluşmasını adeta zorladığını" (Sezen, 2003) söylemek yanlış olmayacaktır. Ayrıca AB'nin bu süreçteki etkisi de yadsınamaz ölçüdedir. AB'de aday ülkelerden bu tür bir yapılanmaya sahip olmaları yönünde talepte bulunmaktadır. Uluslararası kuruluşların özellikle gelişmekte olan ülkelerde bu şekilde bir etkide bulunmalarının nedeni bu ülkelerde politikacılara ve bürokratlara güven duyulmaması ve dolayısıyla bunlarm piyasanın işleyişine müdahale etmelerine engel olunmasını sağlamaktır. Kısacası tüm bunların temelinde ekonomik olan ile politik olanın ayrı olduğu, olması gerektiği, siyasi güçlerin piyasa üzerinde herhangi bir şekilde etkisi olmaması gerektiği düşüncesi yatmaktadır. Bu yaklaşım ülkemizde önemli değişiklikleri beraberinde getirmiştir. Devlete yüklenen roller hızlı bir biçimde, bu yeni oluşuma paralel olarak değişmiştir. Sosyal devlet ilkesi terk edilerek; devlet piyasadan çekilmiş ve devletin işletme rolünden çekildiği ekonominin yönetimini bağımsız idari otoritelere bırakmaya başlamıştır. Kısacası devlet önceden aktör olarak piyasada yer alırken; özelleştirmeler ile bu durumdan çıkmış ve artık bă̆ımsız idari otoriteler eliyle piyasaları düzenler hale gelmiştir. Yaşanan bu süreç çok aktörlü yönetim anlayışını iyiden iyiye ülkemize sokmuştur.

Ekonomik alanda düzenleme yapılması için, kısmen dışsal etkiler ve baskılar ile oluşturulmuş olan bu yapılanmaların kuruluş gerekçelerini minimal devlet yaklaşımına dayalı olarak devlete yüklenen düzenleme görev ve yetkisinin etkin bir biçimde kullanılmasını sağlamak, minimal devlet anlayışına göre piyasaya müdahale gerekçesi olarak görülen piyasa başarısızlıklarından eksik rekabetin giderilmesini sağlamak, rekabetçi bir piyasa düzeni sağlayarak, iktisadi aktörlere, piyasalara güven aşlamak,"genel kamusal yapılanma içerisinde çözümlenemeyen teknik sorunların giderilmesini kolaylaştırmak" (Çolak, 2003), "dışsal şoklara açık ülke ekonomisinin, bu şekilde sürdürülebilir, siyasetten uzak bir yapıya dönüştürülmesinin sağlanması" (Çolak, 2003), piyasaların bürokratlardan, özel çıkar gruplarına, siyasilerden medyaya çeşitli grupların etkilerinden uzak kalmasını sağlamak, piyasaların kısa vadeli popülist politikalardan etkilenmelerini ve bu nedenle kırılgan bir yapıya sahip olmalarına engel olmak, özel önem arz eden belli başlı bazı sektörlerde bu yapılanmalar vasıtası ile uzmanlaşmayı sağlamak, yaşanan özelleştirme süreci sonrasında piyasayı düzenleme ihtiyacını gidermek, sahip oldukları denetim, gözetim ve yaptırım uygulama yetkisi sayesinde yarg1 yerlerinin iş yükünü azaltmak, devletin demokratik yapısı gereği, piyasa işleyişini olumsuz etkileyen unsurları bertaraf edip; çok aktörlü yönetim görevlerini yerine getirmek şeklinde saymak mümkündür.

Genel olarak yukarıda sayılmıs olan amaçları gerçekleştirmek için kurulmuş olan bağımsız idari otoritelerin kurulmasinda, standartlar net olarak ortaya konmamıs, gerekçeler tam olarak belirlenmemiştir, bu kurumlar kurulma gerekliliği doğrultusunda kurulmuşlardır. Ayrıca yabancı ülke örneklerine dayanılarak kurulmuş olmaları da bağımsız 
idari otoritelerin yapılanmasında çok çeşitli problemleri beraberinde getirmiştir. Otoritelerin kurulma aşamalarındaki bu stratejik belirsizlik, işleyişleri esnasında da yapısal bozuklukların görülmesine neden olmuştur. Sonuç olarak ülkemizdeki bağımsız idari otoritelerin oluşması süreci dışsal etmenler ile yukarıda belirtilen nedenlerin yanında, öncelikli olarak dış kuruluşların taleplerine karşllık verebilmek için kurulmuşlar ve bu durum da bağımsız idari otorite yapılanmaları üzerinde süregelen uzun tartışmaların temeli olmuştur. Otoritelerin kurulma aşamalarındaki bu stratejik belirsizlik, işleyişleri esnasında da yapısal bozuklukların görülmesine neden olmuştur.

\subsection{Bağımsız İdari Otoritelerin Sinıflandırılması}

Ülkemizdeki bağımsız idari otoriteleri yapmış oldukları regülasyonun özelliğine göre ve bă̆ımsız idari otoritelerin faaliyet alanlarına göre sinıflandırmak mümkündür. Faaliyet alanına göre sinıflandırırken; ekonomik alanda faaliyet gösterenler ve temel hak ve hürriyetlere ilişkin faaliyet gösterenler olarak ayrım yapabiliriz. Esasen bu ayrım çok kesin çizgiler içermemekle birlikte geçerli sayılabilmektedir. Ayrıca ülkemizde oluşturulan kurumların da daha çok ekonomik düzenleme amacı ile kurulduğunu söylemek gerekir. Belirgin olarak örnek vermek gerekirse EPDK, BDDK, RK ekonomik alanda faaliyet gösteren bă̆ımsız idari otoritelerden sayılabilirken; RTÜK ise temel hak ve özgürlüklere ilişkin otoritelerden sayılabilir. Bu ayrıma ilişkin Ulusoy (2003a), bütün bağımsız idari otoritelerin doğrudan ya da dolaylı olarak hem ekonomik alanda hem de temel hak ve özgürlükler konusunda faaliyet gösterdiklerini dile getirmektedir.

Yapılan regülasyonun özelliğine göre sınıflandırdığımızda ise, otoritelerin çalışma alanları göz önünde tutularak; yapılan regülasyonun tek bir sektör üzerinde mi yoksa genel olarak çok çeşitli sektörler üzerinde mi etkili olduğu noktası ön plana çıkmaktadır. Ülkemiz açısından bakıldığında bağımsız idari otoriteler yaptıkları regülasyonun niteliğine göre, genel nitelikli regülasyon yapan otoriteler ya da genel düzenleyiciler ve sektörel düzenleme otoriteleri olarak ikiye ayrılmaktadır (Ulusoy, 2003a). Bu sinıflandırmaya göre ülkemizdeki bağımsız idari otoriteler değerlendirildiğinde; Kamu İhale Kurumu ve Rekabet Kurumu genel düzenleyiciler olarak karşımıza çıkmaktadırlar. $\mathrm{Bu}$ otoritelerin düzenleme alanları belirli bir sektör ile sınırlı olmayıp, genel düzenleme niteliği taşımaktadır. SPK, BDDK, RTÜK, EPDK ve diğer otoriteler belirli bir sektöre yönelik düzenleme faaliyetini gerçekleştirdiklerinden dolayı sektörel regülasyon otoritesi olarak sayllırlar. 2011 yılında yapılan düzenleme ile yapılanmaya dahil edilen Kamu Gözetimi Muhasebe ve Denetim Standartları Kurumu da genel düzenleyici olarak karşımıza çıkmaktadır.

\subsection{Türkiye'deki Bağımsız İdari Otori- telerin Genel Özellikleri}

Ülkemizde kurulan bağımsız idari otoriteler kendi faaliyet alanları, çalışma düzenleri farklı olmasına rağmen; birbirleri aralarında benzer, idari yapımız içinde farklı özelliklere sahiptirler.

\subsubsection{Bağımsız İdari Otoritelerin Yapısal} Özellikleri

Ülkemizdeki bağımsız idari otoriteler, farklı alanlara ilişkin düzenleme faaliyetinde bulunuyor ve örgütlenme biçimleri farklılıklar içeriyor olsa da bu yapılanmalar belli başlı ortak özelliklere de sahiptirler. Öncelikle ülkemizdeki bağımsız idari otoritelerin mutlak olarak yasama organı tarafından kanun ile kurulmaktadır. Bağımsız idari otoriteler kanunla kurulan, idari ve mali özerkliğe ve kamu tüzel kişiliğine haiz, bağımsız idari kurumlardır.

"Bağımsız idari otoritelerin, yürütmenin anayasal örgütlenmeye dayanan konumundan farklı bir yapı olarak, kendi sorumluluk 
alanları, personelleri, kendi yönetimleri, bütçeleri bulunmaktadır ve bu özellikler itibariyle de klasik yapılanmadan ayrılık göstermektedirler" (Akıncı, 1999). Ancak belirtmek gerekir ki, bağımsız idari otoriteler kamusal hayata hassas sektörlerde devlet otoritesini temsili ile kamusal güç kullanarak hareket ederler.

Bağımsız idari otorite dediğimiz kurumsal yapıların bağımsız nitelikte oluşturulmaları çok çeşitli açlardan önemli sonuçlar doğurmaktadır. Bu kurumlara sağlanan bağımsızlık sayesinde idari ve vesayet denetiminin dışında kalmaları önemli bir ayrıcalık getirmektedir. Ayrıca hukuksal açıdan değerlendirildiğinde de hem bağımsız hem de kamusal yetkiler ile donatılmış olmaları inceleme ve soruşturmalarında "geleneksel yapıların ulaşamadığı bir derinliğe ulaşmalarını sağlamaktadır" (Akıncı, 1999). Bu kurumları merkezi yönetimin hiyerarşisi içerisinde yer almaması da bu kurumların kararları üzerinde doğrudan bir etki gösterememesini sağlamaktadır.

Bağımsız idari otoritelere kuruluş kanunları ile tanınmış olan bu bağımsızlık bu kurumların tamamen denetim dışı oldukları anlamını taşımaz. Otoriteler, "İdarenin bütünlüğü ilkesi gereği, yargısal ve yasal denetime tabi olmalarının yanında, az sayıda da olsa bazı idari denetimlere de maruz tutulabilirler" (Ulusoy, 1999). Bağımsız idari otoriteler her ne kadar bağımsız yapıda olsalar da bu kurumlar da belli smirlar dahilinde, kuruluş kanunları ve diğer yasal çerçeve ekseninde hareket etmektedirler. Bu kurumların bağımsızlıklarının ön plana çıktığı nokta siyasi otoriteden ve diğer piyasa aktörlerinden bağımsız hareket edebilmeleri noktasında önem kazanmaktadır. Ancak şöyle de bir gerçek var ki; bu kurumların oluşturulmaları yasama organı tarafindan çıkarılan bir yasa ile gerçekleştiği gibi, bu yasada değişiklik yapılması ile bu kuruma istenen şeklin verilebilmesi de söz konusu olabilir. Yani yasama organı yasal bir düzenleme ile bu kurumları görev ve yetkilerini değiştirebilir ve bu şekilde de kurumsal yapıya istediği gibi yön verebilir. Dolayısıyla, "bağımsız idari otoritelerin bağımsızlığını garanti eden sihirli bir formülün varlığından söz etmek mümkün değildir" (Tan, 2002). Ayrıca bütçe kanunu da bu kurumların üzerinde etkin bir denetim mekanizması olarak kullanılabilmektedir. Bağımsız idari otoritelerin bütçeleri yasama organının onayına tabi olduğundan gerektiğinde bu kurumların bütçeleri yasama organı tarafindan onaylanmayabilir. $\mathrm{Bu}$ konu da kurumların bağımsızlıkları konusunda tartışmalara neden olabilmektedir. "Bu kurumları yoktan var eden yasama organının kendisidir" (Akıncı, 1999), dolayısıyla çeşitli düzenlemeler vasıtası ile bu kurumların yapısı üzerinde değişiklikler meydana getirebilir. Bu durum da yasal çerçevede bă̆ımsız olarak nitelendirilen bu kurumların bağımsızlıklarını sorgulanır hale getirir. Ülkemizdeki bu kurumların bağımsızlıkları nispi bir bağımsızlık olarak değerlendirilmelidir.

$\mathrm{Bu}$ kurumları incelerken dikkat edilmesi gereken bir diğer nokta da "kurumların yıllık program, hükümet programları ve politikaları ile genel çerçevesi çizilen genel ilkeleri ve ekonomik politikaları göz ardı etmeden hareket etme yükümlülüğünde olmaları" (Karacan, 2001) "alacakları kararlarda bunları dikkate almak durumunda olmalarıdır" (Sobacı ve Parlak, 2005). Yani bağımsız idari otoriteler, kuruluş kanunları, genel mevzuatın yanmda genel ekonomi politikaları ile de bağlı durumdadırlar. Kurumların bağımsızlıkları tüm bu belirtilen sinırlar çerçevesinde oluşmuştur. Bu durum önemli bir çelişki yaratmaktadır. Anlaşılacağı üzere bağımsız idari otoritelerin sahip oldukları bağımsızlık "mutlak" bir bağımsızlı̆̆ı değil, göreli bir bağımsızlığı işaret etmektedir.

Siyasilerin vatandaşlar tarafindan seçilmişler oldukları düşüncesi ile oluşturulan bağımsız idari otoritelerin bağımsızlık dereceleri arasında dengenin kurulmasinı önemli olduğu düşünülmektedir. Bu bakış açısı ile bağımsız idari otoritelere mutlak bağımsızlık tanınması uygun düşmemektedir. Bu kurum- 
ların varlık nedeni olarak siyasilerin her iş ve işlemi bizzat yapamayacakları varsayımı ile siyasilerin bazı düzenleme işlerini bu kurumlar aracılığı ile yaptıklarını savunan görüşler de mevcuttur. Bu bakış açısı ile kurumların idari bağımsılıkları, kurul üyelerinin seçimi gibi unsurlar düşünüldüğünde kısmi nitelik kazanmaktadır. Sonuç olarak görüleceği gibi "bu kurumlar siyaset ve siyasetçinin kısmen de olsa etki alanında siyasete tabi kurumlardır ve politikacıların etki alanının tamamen dışında olmaları düşünülemez" (Karacan, 2001).

Bağımsız idari otorite yapılanmasından önce bir bakanlığa bağlı olarak yapılan işin sonradan bağımsız idari otorite tarafindan görülmesi durumunda da bağımsızlı̆̆a ve işlevselliğe gölge düşürücü önemli sorunlar yaşanmaktadır. İlgili kurumlar kendilerinden ayrılınması konusunu kabullenememekte ve idari yapılanmadaki bağları da devam ettiği için bu kabullenememenin sonucu olarak çeşitli şekillerde etkilerde bulunma yönünde çabalara girişmektedirler. Ülkemizdeki bağımsız idari otoritelerde de bunun örneklerine rastlanmaktadır. Hazine Müsteşarlı̆̆ 1 ve Maliye Bakanlığg'nın SPK üzerinde yine Maliye Bakanlığı'nın KİK üzerinde böyle bir etkisinin olduğu düşünülmektedir.

Bağımsız idari otoriteler; bağımsız yapıya sahiptirler, ancak bağımsızlıkları anayasal güvenceye sahip değildir ve ayn zamanda yargısal denetim dışında da tutulmamıslardır. $\mathrm{Bu}$ kurumların faaliyetlerine ilişkin aldıkları kararlar yargısal denetimin konusu olabilmektedir. Yani bağımsız idari otoritelerin yasama, yürütme ve yargı organları karşısındaki bağımsızlıkları mutlak bir bağımsızlık olmadığı hususuna gelinmektedir. Bă̆ımsızlık tanınması, bu idareler için bir amaç değil, sadece kamu görevlerini daha iyi yerine getirebilmelerinin sağlanması için bir araç olarak düşünülmektedir. Bu kurumlara bağımsızlık verilmesinin en önemli nedeni bağımsız idari otoritelerin kendilerine verilen yetkileri en rahat şekilde kullanarak, yetki alanlarındaki konularda görevlerini en iyi şekilde yerine getirmelerinin sağlanmasıdır. $\mathrm{Bu}$ durumun sağlanması için gereken bağımsızlığın kurumlara mutlaka verilmesi halinde bağımsız idari otoritelerden beklenen kamusal fayda sağlanacak, piyasaların etkin düzenlenmesi sağlanabilecektir.

Yargısal denetimin yanı sıra bu kurumlar iç ve diş denetime de tabidirler. Ülkemizdeki bağımsız idari otoritelerde iç denetime ilişkin ilkeler ve iç denetim faaliyetinin uygulanması, uygulayan birim açısından farklılıklar görülmektedir. Bazı otoritelerde Denetim Birimi Başkanlığı tarafından yapılırken, Teftiş Kurulu Başkanlığı tarafından da yapıldıkları görülmektedir. Dı̧̧ denetim açısından bakıldığında ise bu kurumlar belirlenmiş bir hiyerarşik denetim veya vesayet denetimine tabi değildirler. Dış denetim faaliyetlerini ise yargisal denetim, faaliyet denetimi ve mali denetim olarak üç ayrı kategori olarak sinıflandırmak mümkündür.

Bağımsız idari otoritelerin özelliklerini incelerken işlevsel özelliklerini göz ardı etmemek gerekir. Bu kurumlar, kamu yararı ve kamu düzeninin gereklerine dayalı olarak düzenleme yapma yetkisine sahipken, ayn zamanda bu düzenlemelere ilişkin denetim faaliyetinde bulunabilir ve gerektiği noktalarda bunlara ilişkin yaptırımlar uygulayabilir ki, bu durum oldukça önemlidir.

Bağımsız idari otoritelere düzenleme yapma yetkileri kurucu kanunları ile verilmiştir. EPDK, elektrik enerjisi ve doğal gaz fiyatlandırlmasinm esaslarmm belirlenmesi ve denetlenmesi; BDDK, tasarruf sahiplerinin hak ve menfaatlerini korumak, mali piyasaların istikrar içinde güvenli ve etkin çalışmasını sağlamak üzere bankaların kuruluş, faaliyet, denetim ve tasfiyesine ilişkin esasları düzenlemek hususunda yetkilidir. KİK, kamu ihale düzenine ilişkin tüm mevzuatı, standart ihale dokümanların ve tip sözleşmeleri hazırlamak, geliştirmek ve uygulamayı yönlendirmek gibi yetkilere sahiptir. RTÜK, özel radyo ve televizyon kuruluşlarının uyması gereken asgari idari, mali ve teknik şartlar ile yayın saati, süreleri ve yayımlanacak programların tür 
ve oranlarm belirlemeye; SPK ise sermaye piyasası araçlarının ihracına, halka arz ve satış koşullarına, aracı kuruluşların aracılık faaliyetlerine, sermaye piyasasinın denetimine ilişkin esasları belirlemeye yetkilidir. Bağımsız idari otoriteler kendi görev alanlarına ilişkin olarak konulmuş yasalar ve kendi düzenledikleri ikincil mevzuat çerçevesinde, bunların uygun olarak uygulanıp uygulanmadığını izlemek ve kontrol etmek yükümlülüğüne sahiptirler. $\mathrm{Bu}$ yükümlülüğü yerine getirirken ihtiyaç duydukları bilgi, belgeleri istemek, ilgililerin bilgisine başvurmak ve gerekirse inceleme yapmak ile görevli ve yetkili kılınmışlardır. $\mathrm{Bu}$ yetkilerini kuruluş kanunlarından alırlar. Örneğin; 4628 sayll Kanunun 5 inci maddesine göre; EPDK, onaylı talep tahminlerine dayanılarak Türkiye Elektrik Üretimİletim Anonim Şirketi (TEAŞ) tarafından hazırlanan üretim kapasite projeksiyonu ve iletim yatırım planı ile bu planlara uyumlu olarak mülkiyeti kamuda olan dağıtım tesisleri işleten dağıtım şirketleri tarafindan hazırlanan dağıtım yatırım planlarını onaylamak, gerektiğinde revize edilmesini sağlamak ve onay verdiği yatırım planlarının uygulamalarını denetlemek, piyasada faaliyet gösteren tüzel kişilerin denetlenmiş mali tablolarını incelemek veya incelettirmek ve bu kanunun kendisine verdiği görevleri yerine getirirken konusuna ilişkin olarak gerekli gördüğü her türlü bilgi ve belgeyi tüm kamu ve özel kuruluşlarından ve kişilerden istemek ve/veya yerinde inceleme yapmak yetkilerine sahiptir.

Bağımsız idari otoritelerin etkinlikleri açısından önemli bir avantaj olan özellikleri de, yaptırım uygulayabilme güçlerinin bulunmasıdır. Otoriteler, düzenleme yapma yetkisini kullandıktan sonra, bu düzenlemenin uygulanmasına ilişkin gereken kontrolleri yapabilmekte ve bu düzenlemelere aykırı hareket edilmesi durumunda da bu duruma müdahale edebilmektedirler. Bu da, daha güçlü konuma sahip olmalarını sağlamaktadır. Bağımsız idari otoriteler, ilgili oldukları alana ilişkin idari veya maddi yaptırımlar uygulama yetkisine sahiptirler. $\mathrm{Bu}$ yaptırımlar, kurumlar arasında ilgili oldukları alan itibariyle farklılık göstermeleri nedeniyle, farklı şekillerde olabilmektedir. Parasal cezalar yanında kurumdan kuruma değişiklik göstererek, ruhsat iptali, yasaklama, faaliyet durdurma gibi şekillerde de olabilir. Örneğin; RTÜK, 3984 sayılı Kanunun 3 üncü maddesi uyarınca kanuna uygun faaliyet göstermeyen radyo ve televizyonlarm yayınlarını durdurabilmekte iken, KİK, kanuna aykırı yapılan ihaleleri askıya alabilmekte, iptal edebilmekte veya bunlara ilişkin düzeltici işlemi belirleyebilmektedir. $\mathrm{Bu}$ kurumların yargisal nitelikleri olmadığ halde yaptırım uygulama yetkilerinin olması zaman zaman kuvvetler ayrılığı ilkesine aykırılık yönünde tartışmalara neden olmaktadır. Ancak bu kurumların yaptırım uygulamalarının istisnai olduğu düşünülerek bu tartışmalar sonlandırılabilir.

Kuvvetler ayrımı ilkesine ilişkin tereddütleri barındıran bir başka nokta da bu kurumların uyuşmazlık çözme yetkilerinin olmasıdır. Bağımsız idari otoriteler uyuşmazlıkların çözümüne ilişkin yetkilerini de kuruluş kanunlarından alırlar. Kuruluş kanunları çerçevesinde bu kurumlar uygulamaya koydukları düzenleyici işlemlere ilişkin gereken kontrol ve denetimleri yapmaları ve bunun sonucunda tespit ettikleri aykırllkklara ilişkin yaptırım uygulamaları mevzuatın ilk elden denetimini sağlamakla birlikte, kurumların uyguladıkları yaptırım sayesinde idari yargı yerlerinde çözümlenebilecek hususlar yargı yerlerini meşgul etmeden kısa sürede çözümlenebilmektedir. Yaptırım uygulama yetkilerinin bulunması hem mevzuata tabi kişiler açısından caydırıcılık yaratmakta hem de zaten yoğunluk yaşayan yargının yükünü hafifletmektedir.

4.3.2 Bă̆ımsız İdari Otoritelerin İdari Yapılanmadaki Yeri

Bağımsız idari otoritelerin geleneksel kamu kurumlarından farklılaşan bir yapıya sahip olduğunu vurgulamıştık. İlgili olduk- 
ları alana ilişkin geniş yetkilerle donatılmış kurumlardır. Bağımsız idari otoriteler ilgili oldukları sektöre ilişkin hem yasama, hem yürütme, hem de yargı işlevlerini yerine getirir niteliktedir. Amerika'da alanlarına ilişkin yasama, yürütme ve yargı erkine ilişkin yetkileri bünyelerinde barındırdıklarından dolayı dördüncü erk gibi görülürler. Ülkemizdeki otoritelerin de bu üç erke ilişkin görev ve yetkilerinin olması bu kurumların da dördüncü erk olup olmadığı tartışmalarını gündeme getirmiş olsa da bu tartışmalar yersizdir. Zira kuvvetler ayrıllı̆̆ ilkesi ile bağdaşmayacak şekilde dördüncü bir erkin oluşturulması söz konusu olamaz. Bunun yanında bağımsız idari otoriteler yasama organı tarafından çıkarılan yasalara bağlı olarak faaliyet göstermekte ve yargı organlarmın da denetimine tabidir. Dolayısıyla bu kurumları dördüncü erk olarak değerlendiremeyiz.

Üç erkin dışında değerlendirilemeyen bu kurumların bu üç erk içerisinde hangisine dahil olduğunun açıklı̆̆a kavuşturulması önemlidir. Otoritelerin yasama, yürütme ve yargı erklerinin her üçüne ilişkin çeşitli görev ve yetkileri bünyelerinde bulundurmaları, literatürde bu kurumların bu "üç erkin kesişim kümesinde" (Akıncı, 1999) yer aldığ 1 görüşünün oluşmasına neden olmuştur. Ancak erkler ayrılığı ölçütü dikkate alınarak değerlendirildiğinde, bu kurumlarm daha çok yürütmenin işlevlerine sahip durumda oldukları görülmektedir. "Merkezi idare açısından baktığımızda ise merkezi idarenin yörüngesinden en uzak uyduları şeklinde tanımlanarak ayrı bir kategorileştirme yapılması söz konusudur" (Akıncı, 1999).

Organik açıdan yasama, yürütme ve yargı erklerinin hangi organlardan oluştuğu Anayasamızda açıkça belirtilmiştir. 1982 Anayasası'na göre devlet yetkisi kaynağını Anayasadan alır ve yine anayasaya göre bu yetkiler yasama, yürütme ve yargı olarak sayılmış ve sinırlanmıştır. Anayasanın yürütme erkine ilişkin olan Üçüncü Kısım, İkinci Bölüm İdare Başlığı altındaki 123 üncü maddesinde "İdare, kuruluş ve görev- leriyle bir bütündür ve kanunla düzenlenir. İdarenin kuruluş ve görevleri, merkezden yönetim ve yerinden yönetim esaslarına dayanır. Kamu tüzelkişiliği, ancak kanunla veya kanunun açıkça verdiği yetkiye dayanılarak kurulur." ifadesi yer almaktadır. $\mathrm{Bu}$ maddeden de anlaşıldığı gibi kamu tüzel kişiliğine sahip olan kurum/kuruluşlar yürütme erki içinde tanımlanmışlardır. Kamu tüzel kişiliğine sahip bağımsız idari otoriteler de, bu özellikleri itibariyle yürütme erkine dâhildirler.

5018 sayılı Kanuna göre genel yönetim çatısında toplanmış olan kamu idareleri; merkezi yönetim kapsamındaki kamu idareleri, sosyal güvenlik kurumları ve mahalli idareler olarak üç kısma ayrılmıştır. Merkezi yönetim kapsamındaki kamu idareleri de kendi içerisinde üç sınıfa ayrılmıştır. Bunlar genel bütçeli idareler, özel bütçeli idareler ve düzenleyici denetleyici kurumlardır. Görüldüğü gibi 5018 sayılı Kanun bağımsız idari otoriteleri merkezi yönetim kapsammdaki idareler arasında kategorilere ayırmıştır.

Yine 123 üncü maddeye dayalı olarak değerlendirme yapacak olursak; Türk kamu yönetiminin teşkilatlanmasında merkezden yönetim ve yerinden yönetim şeklinde iki tür örgütlenmeye yer verilmiştir. Merkezden yönetim, devlet tüzel kişiliği altındaki kurumlarda söz konusudur. Bağımsız idari otoriteler, ayrı tüzel kişiliğe sahip olmaları nedeniyle, bu örgütlenme içinde yer edinememektedirler. Yerinden yönetim uygulaması ise; yer ve hizmet yönünden olmak üzere ikiye ayrılmaktadır. Tüzel kişiliklerinden dolayı bağımsız idari otoritelerin yerinden yönetim kuruluşlarına dâhil olması gerekmektedir. Yerinden yönetim kuruluşları da mahalli idareler ve diğer kamu kurumları olarak ikiye ayrılmaktadırlar. Mahalli idarelerin görev alanlarını belli bölge ile sinırlı olması durumunu göz önüne alacak olursak, kurumları bu kategoride değerlendirmek de akılcı olmayacaktır. Ancak bu noktada değişik görüşler ortaya atılmıştır. Bağımsız idari otoritelerin yerin- 
den yönetim kuruluşları arasında sayılıp, mahalli idareler, hizmet yerinden yönetim kuruluşları yanında üçüncü bir tür olarak kabul edilmesini savunanlar mevcuttur. Tan, bu kurumların kamu tüzel kişiliğine haiz kamu kurumları olarak nitelendirmekte; ancak bunların özellikleri, işlevleri, yasal düzenlemeleri dikkate alındığında belirli bir kamu hizmetini görmek üzere kurulan diğer klasik kamu kurumlarından farklılaştıklarını ifade etmektedir (Tan, 2000). Sezen (2003) ise otoritelerin hizmet ölçütlerinin belirli bir coğrafi alanla sinırlı olmamaları ve yöneticilerinin de halk tarafindan seçilmemiş olması nedeni ile yer yönünden hizmet yönetim kuruluşu sayılamayacağı; ancak birer hizmet yönünden yerinden yönetim kuruluşu olduklarını savunmaktadır.

Bu konuda tartışmalar kuruluşları üzerinden uzunca süreler geçmiş olmasına rağmen halen güncelliğini korumaktadır. Ancak bu konuya dair dikkat çeken bir husus da yarg1 kararlarında bağımsı idari otoritelerden bahsedilirken kamu kurumu ifadesinin kullanılıyor olmasıdır.

\subsection{Bağımsız İdari Otoritelerin Görev ve Yetkileri}

\subsubsection{Düzenleme Yetkisi}

Bağımsız idari otoriteler idari yapılanmada yapısal olarak farklı niteliklere sahip olmalarını yanında işlevsel olarak da klasik yapılanmadan farklılık göstermektedirler. Otoritelerin farklılık arz eden en önemli işlevsel özellikleri düzenleme yetkisi olarak karşımıza çıkmaktadır. "Ülkemizdeki yapılanmada kurumlarm kurucu yasaları bir yandan sektörün işleyişine ilişkin temel kuralları belirlemekte; öte yandan da bu sektörü düzenlemek ve denetlemekle görevli bu kurumlara ikincil düzeyde düzenlemeler yapmak için yetki vermektedir.". İdarelere verilen bu yetki, yasal düzenlemeler ile sinirl, onu tamamlayıc ve ona bağımlı bir yetki olarak verilmektedir" (Tan, 2000; Sezen, 2003). Örneğin; KİK, Kamu İhale Kanunu ve Kamu İhale Sözleşmeleri
Kanununa ilişkin bütün mevzuatı, standart ihale dokümanlarını ve tip sözleşmeleri hazırlamak, geliştirmek ve uygulamayı yönlendirmek; SPK; Sermaye Piyasası Kanununun uygulanması açısından sermaye piyasası araçlarının ihracını, halka arz ve satışının şartlarını düzenlemek, sermaye piyasasında, gerektiğinde elektronik ortam da dahil bağımsız denetim faaliyetine ilişkin esasları belirlemek, kurumlarının mali bünyeleri ve kaynaklarının kullanımı ile ilgili standart rasyoları genel olarak ya da faaliyet alanları veya kurumların türleri itibariyle belirlemek, bu rasyoların yayımlanmasına ilişkin usul ve esasları düzenlemek; BDDK ise, düzenlemek ve denetlemekle görevli olduğu sektör veya alanla ilgili uluslararası ilke ve standartlarla uyumlu ikincil düzenlemeleri yapmak ve kararlar almak şeklinde kurumların düzenleme işlevleri ifade edilmiştir.

Bağımsız idari otoriteler düzenleme yetkilerini öncelikle kuruluş kanunları ile kendilerine tanınan görev ve yetkilere aykırı olmadan, bu görev ve yetkilerin uygulanmasını göstermek üzere, özerklik ilkesi çerçevesinde ve üst normlara bağlı kalmak kaydıyla yönetmelik, tebliğ, karar, genelge, bildiri ve başkaca isimler taşıyan düzenleyici işlemler aracılı̆̆ıyla yerine getirirler. Her ne kadar düzenleyici işlem sayılmasa da bazı otoritelerin düzenleme faaliyetinde kullandıkları bir başka yöntem de "özel nitelikli karar"dır. Özel nitelikli kararlar ile düzenleme faaliyeti de yine diğer düzenleyici işlemlerde olduğu gibi kuruluş kanununda verilen görev ve yetkiler çerçevesinde kullanılır. Özel nitelikli kararların diğer düzenleyici işlemler gibi Resmi Gazete'de yayımlanma zorunluluğu da yoktur. Ülkemizde bağımsız idari otoritelerin uygulamalarına baktığımızda ise daha çok tebliğlere başvurulduğu görülmektedir.

Bağımsız idari otoritelerin sahip oldukları düzenleme yetkisinin mutlak ve sinırsız olduğu düşünülemez. Bu durum kuvvetler ayrılığı ilkesine aykırılık teşkil edecektir. $\mathrm{Bu}$ bağlamda otoritelere tanınan düzenleme 
yetkisi ikincil niteliktedir. Bu kurumlar ilgili oldukları sektörlere ilişkin temel düzenlemelerin ötesinde ikincil nitelikte kurallar koyarlar (Gözübüyük, 2004).

\subsection{2 İzleme Denetim Yetkisi}

Bağımsız idari otoriteler kendi görev alanlarına giren konularda ilgili mevzuat çerçevesinde mevcut olan hükümlere uyulup uyulmadığını izlemek ve denetlemek, uyulmadığını tespit ettiği takdirde bazı yaptırımları uygulamakla görevli ve yetkilidir. Bu görevini yerine getirmek adına ihtiyaç duyduğu bilgi ve belgeleri ilgililerden istemek, bunları incelemek görev ve yetkisine de sahiptirler. Otoriteler bu yetkilerini de kuruluş kanunlarından alırlar.

Otoriteler tarafindan istihdam edilen uzmanlar eli ile yürütülen inceleme ve denetim yetkisi kapsaminda istenen bilgi ve belgelerin verilmekten kaçınılması, açıklama yapılmaması durumunda ilgili kişi/kurumlara yaptırım uygulama yetkisi de bulunmaktadır. Otoritelerin yine kuruluş kanunlarında hem bilgi belge istenilmesi hem de yaptırım uygulanmasına ilişkin hükümler yer almaktadır ve bu yetkiler ilgili kanuna bağlı kalmak kaydıyla uygulanmaktadır.

\subsubsection{Görüş ve Öneride Bulunma Yetkisi}

"Bağımsız idari otoriteler düzenledikleri ve denetledikleri alanlar itibariyle uzman kuruluşlar olduklarından; etkinlik alanlarını ilgilendiren konularda resmi ve özel kuruluşlara görgü ve deneyimleri doğrultusunda görüş bildirmek ve öneride bulunmakla yetkili kılınmışlardır" (Akıncı, 1999). Örneğin 5411 sayılı Bankacılık Kanunu'na göre BDDK, para, kredi ve bankacılık politikalarının yürütülmesiyle ilgili konularda, Hazine Müsteşarlı̆̆ı, Devlet Plânlama Teşkilatı Müsteşarlı̆̆ı, Tasarruf Mevduatı Sigorta Fonu ve Merkez Bankası ile karşılıklı mütalâa ve bilgi alışverişinde bulunur. Yine 4634 sayılı Şeker Kanunu'na göre Şeker Kurumu iç fiyat, arz talep dengesi ve spekülatif etkileri dikkate alarak şeker ticaretinde yapılması istenen düzenlemeler konusundaki görüşlerini Dış Ticaret Müsteşarlığına bildirir.

"Öneri ise; ya siyasi iktidara ya da aktif idareye yönelik olarak davranış biçimi benimsenmesi, bir reformu gerçekleştirmesi, bir düzenlemeyi değiştirmesi veya parlamentoya yasal bir değişiklik önerisi için yapılan çağrı olarak düşünülebilir" (Akıncı, 1999). Sermaye Piyasası Kanunu'na göre SPK sermaye piyasasına ilişkin mevzuat değişiklikleri hakkında öneride bulunma yetkisine, Rekabetin Korunması Hakkında Kanuna göre RK, rekabet hukukuna ilişkin mevzuat değişikliklerinde öneride bulunma yetkisine sahiptir.

\subsubsection{Yaptırım Uygulama Uyuşmazlık Çözme Yetkisi}

Bağımsız idari otoritelerin kural koyma denetim yapma yeteneğine sahip olmalarının yanında yaptırım uygulama yetkilerine sahip olmaları bu kurumların otorite olma niteliğini güçlendirmektedir ve bu durumun olmazsa olmaz koşuludur. "Bağımsız idari otoritelere tanınmış olan yaptırım uygulama yetkisi kurumların denetim ve düzenleme işlevlerinin yürütülmesini kolaylaştıran bir silah durumundadır" (Akıncı, 1999). Düzenleme ve denetleme işlevlerinin tamamlayıcısı olan bu işlev her bir otorite için farklılık gösterebilmekte olup; idari para cezası uygulanmasından; faaliyetin askıya alınmasina; lisans, ruhsat iptalinden; faaliyet iptaline kadar uzanan geniş bir yelpazeyi içine almaktadır.

Bağımsız idari otoritelere tanınan yaptırım uygulama yetkisinin bu kurumlara yargisal bir nitelik verip vermediği sıklıkla tartışılmış bir konudur. Bu kurumların yargisal kurumlar olarak görülmesi kuvvetler ayrılığ ilkesine aykırılık teşkil etmektedir. Bu kurumlara tanınan yaptırım uygulama yetkisi istisnai bir durumu ifade etmekte olup; kurumlarm yaptırım uygulaması olağan yetkileri arasında sayılamaz. "Yaptırım 
uygulama yetkisi olağan hale dönerse bu kurumlar mahkeme niteliğinde hareket edecek, mahkeme olarak görülmeleri de kurumların asıl özellikleri olan etkin denetim yapma ve düzenleme işlevini sekteye uğratacaktır. $\mathrm{Bu}$ nedenle bağımsız idari otoriteler yaptırım uygulama ve uyuşmazlık çözme işlevlerini yerine getirirlerken, idari etkinlik ve usul güvenceleri arasında denge kurmalı, yaptırımlarda ceza hukuku ve ceza yargılaması ilkelerine uymalı ve bu kurumların yargı organı değil, idari organlar olduğu unutulmamalıdır" (Ulusoy, 2003b). Ayrıca bağımsız idari otoriteler yaptırım uygulanması sürecinin başlaması öncesinde yapılan aykırılığa ilişkin ilgilileri uyarmakta, düzeltici işlem tavsiye etmekte, savunmasına başvurmaktadırlar. Tüm bu girişimlerin sonuçsuz kalması sonrasında yaptırım işlemleri gerçekleşmektedir. Bu açıdan da bakıldığında bu kurumları yargısal kurumlar olarak değerlendirmemek uygun olacaktır. $\mathrm{Bu}$ kurumların uyuşmazlık çözme yetkilerinin olması yargısal niteliklerine işaret etmekten çok, kurumların uzman bakış açısı ile yargıya yardımcı rol üstlendiğini göstermektedir.

\section{5 Ülke Karşılaştırması}

Ülkemizde kamu mali yönetimi reformuna işaret eden, ekonomiklik, verimlilik, hesap verilebilirlik, saydamlık konularını bütün olarak ele alan düzenleme 5018 sayılı Kamu Mali Yönetimi ve Kontrol Kanunu'dur. Diğer ülkelerde olduğu gibi ülkemizde de var olan kamu yönetimine ilişkin sorunların çözümüne yönelik hazırlanmış olan kanun sistemdeki dağınıklığın bertaraf edilmesini, bu şekilde de kamu kaynaklarında israfın önlenmesini să̆lamak amacındadır. Devletin mevcut yapısı ile bahsi geçen hususların sağlanması, kamu hizmetlerinin etkin, sağlıklı ve hızlı bir şekilde sunulması çok mümkün görünmemektedir. Devletin hantal bürokratik yapısı kamu hizmetlerinin sunumu konusunda önemli problemler oluşturmaktadır. Yaşanan sorunlar ve küre- sel ölçekte yaşanan gelişmelere de paralel olarak, çeşitli kesimler tarafından siklıkla eleştiri konusu edilen kamu yönetimi ve kamu mali yönetimi anlayışının değişmesi ihtiyacı oluşmuştur. Bu değişim ihtiyacının filiyata dökülmesi çeşitli çevrelerin bu yöndeki istemlerinin yanında uluslararası alandaki mali kuruluşlar ile AB'ye üyelik sürecinde $\mathrm{AB}$ müktesebatına uyum sağlanmasının gerekli gördüğü gerekliliklerden oluşmuştur. Yönetim kavramının yerine yavaş yavaş alan yönetişim kavramı 5018 sayılı Kanun ile daha da temellendirilmiştir denebilir. Kamu yönetimi reformu ile merkezi devletin pek çok görevi "düzenleyici devlet" anlayışı doğrultusunda düzenleyici otoritelere aktarılmaktadır (Ataay, 2006). Ülkemizde bağımsız idari otoritelerin ilk örgütlenmeleri 5018 sayılı Kanundan öncesine rastlamakla birlikte; bu kanun ile otoriteler toplu olarak düzenlenmişlerdir.

Türkiye'deki bu kurumlar uzunca bir süre kamuoyunun ilgisini çekmemiş ve kamuoyu gündemini meşgul etmemiştir. Ancak özellikle 2000'li yıllarda giderek sayılarmın da artması ile birlikte bu kurumlar kamuoyunda giderek artan bir yer edinmeye başlamıslardır. Üst kurulların Türk kamuoyunda tartışlır hale getiren gelişmenin Radyo ve Televizyon Üst Kurulu'nun ekran karartmalarıyla başlayan ve Bankacılık Düzenleme ve Denetleme Kurumu'nun kurulması ile içi boşaltılan batık bankalarm Tasarruf Mevduatı Sigorta Fonu'na devredilmesi sürecinde yaşanan olaylarda gizli olduğunu söylemek yanlış olmayacaktır (Aydin, 2007).

Bağımsız idari otorite yapılanması her ne kadar ABD'de 19 uncu yüzyılın sonlarında idari yapılanmaya dahil olmuş olsa da, Kita Avrupa'sında bu yeni yapilanmanın yaygınlaşması 20 inci yüzyılı ikinci yarısında olmuştur. "Bu dönemde küresel bir olgu haline gelen bağımsız idari otoriteler aynı tarihsel dönem içerisinde benzer işleyişe sahip olarak ortaya çıkmışlardır" (Bayramoğlu Özuğurlu, 2005b). 1970 ve sonrası süreçte Kita Avrupa'sinda müdahaleci 
devlet anlayışından düzenleyici devlet anlayışına geçiş yaşanmaktadır. "Özelleştirme, piyasalar ve kamu sektöründe rekabeti arttırmayı hedefleyen liberalizasyon, refah politikalarında reform ve düzenleme politikalarındaki değişiklikler bu sürecin belirleyicisidir ve bağımsız idari otoriteler de bu sürecin en belirgin göstergeleri olarak kendilerini göstermektedirler" (Majone, 1994).

Düzenleme otoritelerinin oluşturuldukları dönem açısından Kıta Avrupa'sı ile ABD arasında fark bulunmasının nedeni piyasa düzenleri ve anlayışları açısından ikisi arasında bulunan farklılıklardır. ABD'deki bakış açısına göre piyasalar düzgün işleyen yapilardır ve sadece istisnai durumlarda piyasaya müdahale edilmesi gerektiği öngörülmektedir. Kıta Avrupa'sı açısından bakıldığında ise, piyasa sistemi ABD'deki kadar güvenilir görülmemektedir. Dolayısıyla bu bakış açısındaki farklılaşma piyasanın düzenlenmesi konusunda da farklllıkları ortaya çıkarmıştır. İlk örneği ABD'de görülen bağımsız idari otoritelerin buradaki oluşturulma nedeni esasen yasama organının, yürütme organına duyduğu güvensizlikten kaynaklanmaktadır. Bağımsız idari otoritelerin oluşturulmaları ile yürütmenin bazı alanlarda siyasi etki göstermesinin önüne geçilmiş olacağı düşüncesi hâkimdi.

Pek çok çeşitli nedenler ile kurulmuş olan bağımsız idari otoriteler gerek kuruluşları gerekse örgütlenmeleri açısından ülkeden ülkeye farklılık göstermektedirler. Küreselleşme süreci ile birlikte liberalizmin öncülüğ̈̈nde bağımsız idari otoriteler $\mathrm{ABD}$ sınırlarının dışına çıkmış ve yayılmaya başlamıştır. Özellikle 1980 sonrasında özelleştirme uygulamaları ile birlikte Avrupa ülkelerinde yaygınlaştığı görülmektedir.

Amerika Birleşik Devletleri'nde ise bu kurumlar çok daha önceki dönemde vücuda gelmiş, özel sektör tarafindan bizzat yürütülen faaliyetlerin düzenlenmesi noktasında görev üstlenmişlerdir. Kita Avrupa'sı ülkelerinde ise Anglo-sakson ülkelerine kıyasla daha sonraki tarihlerde (1970'ler) yaygınlaşmaya başlamıştır. Ülkemizde de olduğu gibi Kita Avrupa'sinda da bağımsız idari otoriteler müdahaleci devletten düzenleyici devlete geçiş sürecinde oluşmuş kurumsal yapılardır. Bu kurumların nitelikleri ülkeden ülkeye farklılık göstermektedir. "ABD'de bu kurumlar devletin güçlerinden biri gibi var olurken; Avrupa'da sisteme dahil edilerek; yürütme gücüne dahil, ancak kendine özgü kuruluşlar olarak devlet organizasyonu içerisinde yerlerini almışlardır" (Müftüoğlu, 2001). Bu duruma örnek olarak Fransa'daki bağımsız idari otoriteleri vermek doğru olacaktır. Fransa katı bir bürokratik yapıya sahip olması nedeniyle yetki devri konusunda daha sıkı davranmıştır. Fransa'daki bağımsız idari otoritelerin niteliklerine bakıldığında bu sonuca varmamız kolay olacaktır. Ülkemizde ayrı tüzel kişiliğe sahip olarak kurulmuş olan bağımsız idari otoriteler Fransa'da ayrı tüzel kişiliğe sahip bulunmamaktadırlar. Ayrı tüzel kişiliğe sahip olmamaları otoritelerin bağımsızlık, özerklik niteliğine gölge düşürür bir durumu ortaya çıkarmaktadır.

Bağımsız idari otoriteler her ne kadar daha çok devletin müdahaleci kimliğinden sıyrılıp düzenlemeci kimliğine büründüğü noktada ortaya çlkmış olsalar da; esasen, devletin ekonomik faaliyetlere müdahale araçlarından biri olarak da karşımıza çlkabilmektedir. $\mathrm{Bu}$ noktada müdahaleci kimliğin ölçüsünü belirleyecek olan da bu kurumların bağımsızlıklarıdır. Bu nokta görüldüğü gibi önemli bir çelişkiyi barındırmaktadır. Stratejik öneme sahip sektörlerde piyasanın işleyişine devlet müdahalesinin önlenmesi amacı güdülürken, düzenleme adı altında bu önemli sektörlerin işleyişinde devlet eli rol oynamaktadır. Devletin bu alanlarda bağımsız idari otoriteler vasıtası ile düzenleme işlevini yerine getirmesi esasen piyasadaki var olan aksaklıklarm düzenlenmesi gereği olarak görülmektedir, ancak bu noktada düzenleme çerçevesi önem arz etmektedir.

İktisadi aktörlerin bireysel çıkarları peşinde koştukları ve bu noktada bireysel çıkar 
maksimizasyonunun sosyal faydayı maksimize edemeyeceği düşünülmektedir. Sosyal faydanın maksimizasyonunun sağlanması için mutlaka devlet elinin işin içine girmesi gereği ortaya çıkar. Bir bakış açısına göre devletin bağımsız idari otoriteler eliyle piyasaya müdahalesi, devlet müdahalesi olarak değil de, piyasa ekonomisinin etkin ve sağllklı bir biçimde işlemesinin temini adına bir sigorta olarak görülür. Ancak bu durumun ne kadar gerçekçi ve genel geçer olduğu tartışma konusudur.

Daha önce üzerinde durulan bir başka konu da ülkelerin yapılarının bu tür düzenleyici kurumlar üzerindeki etkileridir. Bağımsız idari otoriteler gerek örgütlenmeleri, gerek ülke içindeki konumları itibariyle ülkeler arasında farklllık göstermektedir. Dolayısıyla otoritelere yapılan olumlamalar ve eleştiriler de bu durumdan etkilenilerek ortaya çıkmaktadır. Katı bürokratik yapıya sahip ülkelerde bu kurumlara yetki devri ideal modeldeki şekilde yapılamamakta, dolayısıyla da beklenen olumlu sonuçlar elde edilemeyebilmektedir. Ülkelerdeki bürokratik yapıdan kaynaklı sorunlar bulunması durumunda bu kurumlardan beklenen sonuçlar elde edilemeyecektir. Bu noktada oluşturulan bağımsız idari otoriteleri idari yapılanmada karmaşa yaratan yapılar olarak değerlendirmek de doğal bir sonuç olacaktır. Bağımsızlık kavramının kullanılması ülkeler arasında farklılıklar göstermektedir. "Fransa, İtalya ve Bulgaristan'da bağımsızlık kavramı kullanılırken; bazı ülkeler bu kavram yerine yansızlık, tarafsızlık ifadesini kullanmaktadırlar" (Tan, 2000). Bağımsız idari otoriteler açısından bağımsızlık kavramı temelde düzenledikleri alanlar ile ilgili olarak aldıkları kararlar ve yetki kullanımında yönlendirmelerden uzak olmasını ifade eder. Daha açık bir ifade ile bağımsız idari otoritelerin başta siyasi otorite olmak üzere, diğer kurum, kuruluş, baskı ve çıkar gruplarının etkilerinden uzak olması, bunların yönlendirmelerine maruz kalmaması ve düzenledikleri alanlara ilişkin serbestîlerinin olması anlamını taşır. Bağımsızlık bazı çevrelerce sadece siyasi etkilerden bağımsızlık olarak algılanmaktadır ki bu yanlış bir bakış açısıdır. Siyasetten bağımsızlığın yanında piyasalardan, diğer kurumlardan ve diğer tüm aktörlerden bağımsızlık anlaşılmalıdır. Zaten bu kurumlara ayrıcalıklı bir statü tanınarak, bağımsızlık verilmesinin en önemli nedeni çeşitli çıkar grupların etkilerinden uzak tutulabilmesinin sağlanmasıdır. Bu otoritelerin yürütme organı karşısında güçlendirilerek, yargı bağımsızlı̆̆ına benzer bir biçimde bağımsızlık sağlanmaya çalışılmıştır. Ancak şunu da açıklıkla ifade etmekte fayda var ki; bu kurumların kuruluş kanunları ile elde ettikleri bağımsızlık yargı bağımsızlı̆̆ındaki gibi anayasal temelli bir bağımsızlık değildir. Yargı bağımsızlığı temelini anayasadan alırken; bağımsız idari otoritelerin bağımsızlı̆̆ı aslında yasaların öngördüğü çerçeve ile sinırlı bir bağımsızlıktır. Anayasal güvenceye sahip olmadıklarını da düşünecek olursak, yasal çerçevede gereken değişiklik yapılarak bu bağımsızlı̆̆a gölge düşürülebileceği de aşikârdır. Ayrıca bir noktayı daha belirtmekte fayda vardır. Demokrasinin bir gereği olarak parlamentonun kendilerine yetki devretmeleri ile görev ve yetkilere sahip olan, seçilmiş siyasi iktidar tarafından atanan üye ve başkan ile kararlar alıp, idare edilen bu kurumlar bu durumun bir sonucu olarak belli şekillerde hesap vermek zorundadırlar. Aksi halde görev ve yetki sahibi oldukları halde sorumluluk hissetmezler ki bu durum da yönetim ilkeleri ve demokrasiye tamamen aykırıdır.

\section{Sonuç}

$\mathrm{Bu}$ çalı̧̧mada dünyanın birçok yerinde aynı zaman paralelinde ortaya çıkan devletin dönüşümü çabaları ve bu durumun yansımaları olan bağımsız idari otoriteler ele alınmıştır. Bu kurumsal yapıların ortaya çıkış süreçleri ve dönemleri, kurulma gerekçeleri, idari yapılanmadaki konumları, çalışma düzenleri, bağımsızlık ve özerklikleri, geleneksel idari kurumlar ile ilişkileri ince- 
lendiğinde çeşitli sonuçlara ulaşılmaktadır. Ancak bu sonuçların hangi ülke ve gelenek çerçevesinde değerlendirildiğinin dikkate alınması önem arz etmektedir.

Özellikle 1980'li yıllarla birlikte öne çıkan liberalleşme süreci ile birlikte devletin işleyiş biçimi ve buna paralel olarak idari yapılanmasında önemli değişiklikler görülmüştür. Devlet örgütünün küçültülmesi söylemi ile üretici kimliğini kaybeden devlet ekonomide eskisinden farklı bir role bürünmüştür. Bu durum kamusal gücü kullanan aktörleri değiştirmiş, karar alma süreçlerinde hükümet dışı aktörlerin de aktif olarak yer aldığı bir dönem başlatmıştır. Ulus devlete atfedilen önem bu dönemle birlikte azalmış ve bunun paralelinde küreselleşme sürecinin doğal bir sonucu da olarak ulus devlet hegemonyasının yerini uluslararası şirketler almıştır. Küresel ölçekteki bu süreç müdahaleci devletten düzenleyici devlete geçiş süreci olarak ifade edilmektedir.

Düzenleyici devlet modelinin kurumsal yapılanmada ortaya çıkardığı en önemli yenilik olan bağımsız idari otoriteler bu noktada karşımıza çıkar. Küresel ölçekteki liberal politikaların yansımaları ülkemizde de özellikle 1980 sonrasında yoğun bir biçimde öne çıkmaktadır. Bu yeni yaklaşımın bir ürünü olan bağımsız idari otoritelerin de liberalleşme yönünde önemli bir adım olan "24 Ocak 1980 Kararları"nın ardından ülkemiz idari yapılanmasında ilk örnekleri görülmüs ancak devletin düzenleyici rolü çerçevesinde esas olarak 1999 yılı ve sonrasında gerek yapısal, gerek işlevsel özellikleri ile diğer kurumsal yapılanmalardan farklllık göstermekte olan bu kurumlar yaygınlık kazanmışlardır. Ülkemizdeki bağımsız idari otoriteler yasama organınca çıkarılan kanun ile kurulan idari ve mali özerkliğe sahip biçimde oluşturulmuş kamu tüzel kişileridir. $\mathrm{Bu}$ kurumlarm ayrı tüzel kişiliğe sahip olmaları gerek idari, gerekse mali açıdan kendine özgü araçlarının bulunmasını sağlamakta olup; bu durum bağımsız yapıların da temin eder niteliktedir. $\mathrm{Ku}-$ rumların bağımsızlıkları nisbi nitelikte olup; mutlak karakter taşımamaktadır. Kurul üyelerinin görev sürelerinin belirli bir süreyle sınırlı tutulması, görev süreleri dolmadan belirli koşullardan dışında görevden alınamamaları, belirli güvenceler tanınmış olması, yürütme organının bu kurumlar ve kurumların kararları üzerinde yaptıkları işlemlerin geçersizliği sonucunu doğuracak işlemler yapamayacak olmaları gibi durumlar bu kurumların bağımsızlıklarını göstermektedir. Kurumların bağımsızlıkları tamamen denetimden yoksunluk anlamma da gelmemektedir. Bu kurumlar üzerinde mali denetim, yargisal denetim ve faaliyet denetimi söz konusudur. Ayrıca her ne kadar siyasetten bağımsız yapıları ile tezat bir durum oluşturuyor olsa da, bu kurumlar hükümet programları ve yıllık programlarla da bağlıdırlar. Kurumlar üzerinde hiyerarşik denetim ya da vesayet denetiminin olmayacağı kurumların kuruluş kanunlarında özellikle belirtilmiştir, ancak bunun yanında kurumlar yine kurulus kanunlarmda bir bakanlık ile ilişkilendirilmişlerdir. Kurumların merkezi idare dahilindeki bir bakanlıkla ilişkilendirilmelerinin farklı yapılanmalarına rağmen, idarenin bütünlüğü ilkesi çerçevesinde idare ile aralarmda bir bağ kurulmaya çalışılmasından kaynaklandığı düşünülmektedir.

Çeşitli ülkelerde farklı gerekçeler ve etmenler nedeni ile oluşturulmuş bağımsız idari otoriteler ülkemizde küreselleşmenin baş aktörleri olan AB, DB, IMF gibi uluslararası yapılanmaların talepleri doğrultusunda yeni küresel dünyanın yarattığı yapılar olarak fazlaca sorgulanmadan, konumları tartışılmadan oluşturulmuşlardır ve aynı zamanda kanuni çerçeve kapsamlı bir mevzuat çalışması gerçekleştirilmeden, ülke gereksinimleri dikkate alınmadan, diğer ülke uygulamalarmda mevcut mevzuatın çevirilerinden faydalanmak suretiyle yapılmıştır. $\mathrm{Bu}$ durumdan çıkarılacak en önemli sonuç bu kurumların ortaya çıkan ihtiyaçlara dayalı olmadan, kurulma zorunlulukları doğrultusunda kamu yönetimine dahil edilen yapılar olduklarıdır. 
$\mathrm{Bu}$ kurumlar yönetişimin kurumsal ayă̆ını oluşturmaktadırlar ve yönetişim yetkinin merkezileşmesine engel olan; yetkinin alt ve üstle paylaşımını öngören bir model öngörmektedir. Ancak ülkemizde bu durumun aksine bir yapılanma oluşturulmuştur. Ayrıca ülkemizdeki bağımsız idari otoritelere ilişkin bir eleştiri konusu da aralarmndaki eşgüdümün sağlanması noktasındaki aksaklıklardır. Farklı farklı sektörlere yönelik oluşturulmuş olan bu kurumların aralarında eşgüdüm ve işbirliğinin sağlanması piyasa ekonomisinin işlerliği noktasında önem arz etmektedir.

Küresel akımların etkileri doğrultusunda oluşan kurumların tam olarak kendilerinden beklenen etkileri gösterdiklerini söyleyebilmek tartışmalıdır. Bu kurumları ve ilgili sektörleri doğru olarak inceleyerek, beklenen olumlu sonuçları verebilecek şekilde yeniden yapılandırmak önem arz etmektedir. Bu yeniden yapılandırmanın temelini kurulus aşamalarında göz ardı edilmek durumunda kalınan içsel faktörlerden yararlanmak oluşturmalıdır. Bunun yanında, yetki alanları açık bir biçimde belirlemeli, kurumların yetki smırları konusuna dikkat edilmeli, bağımsızlıklarına zarar verilmesini önleyecek şekilde yetki alanları belirlenmeli, diğer kamu kurum kuruluşları ile ilişkileri net bir biçimde ortaya konmalıdır. Otoriteler ve diğer kamu kurumları arasında yetki çatışması yaşanmasını önleyici tedbirler alınmalı, kurumlar arasındaki işbirliği ve eşgüdüm sağlanmalıdır.

Bağımsız idari otoritelerin kararları ilgili sektör üzerinde önemli etki yapabileceği için bunun yansıması olarak da ekonominin bütününü önemli ölçüde etkileyebilecektir. Dolayısıyla ülkedeki otoritelerin yapılandırılmasında hassasiyet gösterilmesi önemlidir. Keyfiyete dayalı kararlar alınması ülke ekonomisi üzerinde önemli sorunlar yaratabilecek, ülkeyi darboğaza sokabilecektir. Aynı şekilde kurumlarda alınan kararların rasyonel niteliği, sektörde olumlu etkiler yaratıp, yaygin etkisi ile ülke ekonomisini olumlu seyre sokacaktır.
20 inci yüzyılın son çeyreğinden beri önde olan yaklaşımlarda vurgu yapılan en önemli hususlardan biri siyaset ile ekonominin birbirinden ayrılmasıdır. Liberal söylemlerin temelini oluşturan bu argüman minimal devletin varlığ $\breve{g}_{1}$ ile kendini göstermiş ve yapılan çeşitli çalışmalarla da desteklenmiştir. Bağımsız idari otoritelerin işlevsellikleri de ekonomi ile siyasetin ayrılması noktasında ortaya çımaktadır. Kurumların siyasetten bağımsız hareket edebilmeleri bağımsız ve özerk yapılarına bağlıdır. Bu durumda ince bir çizgiyi işaret etmektedir. Siyasetten uzaklaşmak, bağımsız olmak adına, serbesti fazla genişletilip, keyfiliğin öne çımaması da önemlidir. Ayrıca tarihsel gelişmenin de gösterdiği ve bazı düşünce okullarının vurguladığı gibi, ekonomi ve siyaset gibi birbirinden kopuk iki düzeyin varlığı da tartışmalı bir konudur.

Piyasa ekonomisinin işlerliği noktasında önemli olduğu bilinen bu kurumsal yapıların küresel ölçekte sorgulanır hale gelebildikleri görülmektedir. Yaşanan küresel krizin etkisi ile etkisini yitirmiş olan ulus devlet yeniden öne çıkmaya başlamış ve önceki süreçte yerini biraktığ 1 uluslararası organizasyonların yeniden yerini almaya başlamıştır. Ulus devletin güçlenmesi süreci bağımsız idari otoritelerin de varlık gerekçelerinin sorgulanmasını beraberinde getirmektedir.

Genel bakış açısı, bağımsız idari otoritelerin genel özellikleri ve kuruluş gerekçeleri ile ters düşmekle birlikte; bağımsız idari otoritelerin politikacıları sorumluluktan kurtarmak için öngörülmüss yapılar oldukları da, kimi çevrelerce, ileri sürülmüştür. Bu görüştekiler, politikacıların oy kaygısı yaşamadan, halkçı olmayan politikaları bağımsız idari otoriteler vasitasiyla uygulamaya koyabileceklerini ve bu nedenle bu yeni kurumsal yapılanmayı tercih ettiklerini savunmaktadırlar. Ancak bu yaklaşım bu kurumların esas yapı taşları olan özerklik, bağımsızlık nitelikleri ile örtüşür nitelikte değildir. Aslında bu bakış açısının oluştuğu ülkenin niteliğini dikkate almakta fayda vardır. Ülkemizde de benzer düşünceler tartışlmıştır. Politik güçlere 
güvensizliğin söz konusu olduğu ülkelerde bu tartışmaların olması doğaldır. Otoritelerin yapilanmaya dahil edilmesi ister istemez siyasi bir süreçle gerçekleşmiştir. Dolayısıyla her ne kadar diğer ülke örneklerinden yola çıkarak, serbest piyasa ortamının temini için, bağımsız ve özerk nitelikte oluşturulmuş olsalar da ülkedeki siyasi güvensizlik bu kurumlara olan güveni de etkilemiş, öngörülenin aksi çalışmalar yürütüleceği şüphesini doğurmuştur.

Ayrıca bağımsız idari otoritelerin kurulmalarında her ne kadar ekonomik yapiya, sektörlere, küreselleşme sürecine ilişkin gelişmeler etkili olsa da, ülkemizde ve başkaca birçok gelişmekte olan ülkede oluşum süreci açısından uluslararası kuruluşların bu konudaki etkileri de göz ardı edilemez ölçüde büyüktür. Küreselleşen dünya ile ulus devletlerin yok oluşu dış etkileri arttırmış, uluslararası kuruluşlar bağımsız idari otoritelerin kuruluşlarını teşvik eder hatta bazen çeşitli uygulamalar eli ile zorunlu kılar hale gelmişlerdir. Özellikle gelişmekte olan ülkeler açısından, ülkeye ilişkin güven işareti olarak bu kurumların varlı̆̆ 1 önemsenmektedir. IMF'nin uyguladı $\breve{g}_{1}$ pek çok istikrar programında ülkelere koşul olarak bağımsız idari otoritelerin kurulmasını şart koşması görülmektedir. Bunun yanında Ekonomik Kalkınma ve İşbirliği Örgütü, Avrupa Birliği gibi bazı başka uluslararası kuruluşların da bu yapılanmayı teşvik ettikleri görülmektedir. Ülkemizde de bunun örneklerini görmek mümkündür.

Görüldüğ̈̈ gibi, özellikle Türkiye gibi az gelişmiş ülkelerde bağımsız idari otoritelerin oluşturulmalarını sadece ülke içi, sektörel etmenlerle açıklamak kesinlikle yanlış bir yaklaşım olacaktır. Bu şekilde çeşitli zorlamalarla oluşturulmuş olan kurumlara ilişkin tedirginlik ve güvensizliğin yaşanması da doğaldır. İdari yapılanma içerisinde önemli yer edinmeye çalışan bu kurumsal yapiların içsel etmenler oluşturulmadan kurulma gerekliliği doğrultusunda mecburi kurumsal düzenlemeler ile oluşturulmaları bu ülkelerde etkin işlerlik kazanamamasına ve olumsuz fikirler oluşmasına neden olmaktadır.

Ayrıca göz ardı edilmemesi gereken bir diğer husus da bağımsız idari otoriteler dediğimiz yapılanmaların ülkelerin finansal sürdürülebilirliğinin temini adına oluşturulmuş yapılar olmalarıdır. Ülke kredibilitesini temin etmek üzere oluşturulmuş bu yapilarm hükümetlerin politika yapma yetkisini tam olarak ellerinden almadığ $\breve{l}$, sadece içinde özgürce hareket edebilecekleri ama dışına da çıamayacakları, yol gösterici bir hat sundukları ileri sürülmektedir. "Bunun yanında otorite yapılanması ile seçilmişlerin mali kararlar üzerindeki etkisinin azaldığı ve bu durumda da toplumsal iradenin de dışlandığı vurgulanmakta; aynı zamanda da mali alanın teknik alanın inisiyatifine birakılmasinın yalnızca parlamenter demokrasinin değil, aynı zamanda toplumsal iradenin dişına çıkarılarak hem demokrasinin hem mali alanın depolitizasyona uğratılmasının sonuçlarının daha geniş bir toplumsal düzlem içinde görülmesi gerektiği yönünde eleştirilmektedir" (Gürkan ve Karahanoğulları, 2010). Sonuç olarak yeni modelin küresel kapitalist modelin etkisi ile siyasal iktidarın şekillendiriliyor olması önemli bir gerçekliktir.

\section{Kaynakça}

Acar, M., Emek, U., ve Zenginobuz, U. (2002). Bağımsız düzenleyici kurumlar ve Türkiye uygulaması. İstanbul: TÜSIAD,(Türk Sanayicileri ve İşadamları Derneği). https://tusiad.org/tr/yayinlar/ raporlar/item/1883-bagimsiz-duzenleyici -kurumlar-ve-turkiye-uygulamasi.

Akıncı, M. (1999). Bağımsız İdari otoriteler ve ombudsman. İstanbul: Beta Yayınları.

Ataay, F. (2006). Neoliberalizm ve devletin yeniden yapılandırılması. Ankara: De Ki Basım Yayım Ltd. Şti.

Atay, E. E. (2006). Bağımsız idari otoriteler ve türkiye uygulaması. Gazi Üniversitesi Hukuk Fakültesi Dergisi, 10(1), 259-293. https://dergipark.org.tr/en/pub/ahbvuhfd/ issue/48131/608789.

Aydın, Y. (2007). Türk kamu yönetiminde yeni bir model olarak üst kurullar (Yayımlanmamış Yüksek Lisans Tezi). Konya: Sakarya Üni- 
versitesi Sosyal Bilimler Enstitüsü. https:// tez.yok.gov.tr/UlusalTezMerkezi/TezGoster ?key=Mir2lXQK1dkmQ9Ige3PZbj8oehKfEOQ5X2puw _vvV7D67k60BhPpsu8ZgfBGsfNN.

Bahran, G. (2002). Özerk kurumlar hakkında rapor. Sayıştay Dergisi(46-47), 113-140. https://www.sayistay.gov.tr/tr/Upload/ 95906369/files/dergi/pdf/der46-47m4.pdf.

Bayramoğlu Özuğurlu, S. (2005a). Türkiye'de devletin değişen karakteri ve düzenleyici reformlar. Toplum ve Hekim, 20(1), 4152. http://www.belgelik.dr.tr/toplumhekim/ kayit_goster .php?Id=YsCRcZNAf1I.

Bayramoğlu Özuğurlu, S. (2005b). Yönetişim zihniyeti türkiye'de Üst kurullar ve siyasi İktidarın dönüşümü. İstanbul: İletişim Yayınları.

Bertozzi, D., ve Burgunder, L. (1990). Business, government, and public policy:concepts and practices. Englewood Cliffs: Prentice Hall.

Bhattacharya, S., ve Patel, U. R. (2003). Markets, regulatory institutions, competitiveness and reforms (Theme Paper No. 5). Cairo: Workshop on Understanding Reform. https://pdfs.semanticscholar.org/8904/ c22ef7050ada766a3d5dee680dcd09c70e14.pdf.

Çolak, M. (2003). Üst kurulların ortaya Çıkış gerekçeleri, denetimi ve İdari sistemdeki konumları. Yaklaşım Dergisi, Yıl: 11(125), 83-88.

DPT. (2000). Kamu yönetiminin iyileştirilmesi ve yeniden yapılandırılması (Özel İhtisas Komisyonu Raporu No. DPT: 2507 - ÖİK: 527). Ankara: Devlet Planlama Teşkilatı.

Duran, L. (1997). Türkiye'de bağımsız idari otoriteler. Amme Ídaresi Dergisi, 30(1), 3-11.

Ekiz, C. (2010). Türkiye'de rekabet yönetimi. Ankara: Siyasal Kitabevi.

Emek, U. (2002). Bağımsız düzenleyici kurumlar ve türkiye uygulaması (Rapor No. TÜSİAD-T/2002-12/349). İstanbul: Türk Sanayicileri ve İş Adamları Derneği (TÜSİAD). https://tusiad.org/tr/yayinlar/raporlar/ item/1883-bagimsiz-duzenleyici-kurumlar-ve -turkiye-uygulamasi.

Eren, O. (2004). Bağımsız düzenleyici kurumların personel yapısı. Ankara: TODAIEE.

Gilardi, F. (2005). The institutional foundations of regulatory capitalism: The diffusion of independent regulatory agencies in western europe. The ANNALS of the American Academy of Political and Social Science, 598(1), 84-101. doi:10.1177/0002716204271833

Gözübüyük, c. (2004). Türkiye'nin yönetsel yapısı. Ankara: Turhan Kitabevi.

Güler, B. A. (2005). Yeni sağ ve devletin değişimi. Ankara: İmge Kitabevi.

Güney, A. (2006). Bob jessop'ta yönetişim kavramı: Stratejik İlişkisel devlet biçiminden yönetişim biçimine. MEMLEKET Siyaset Yöne$\operatorname{tim}(2006 / 1)$, 153-171. http://www.yayed.org/ uploads/yuklemeler/msy-1-8.pdf.

Gürkan, C., ve Karahanoğulları, Y. (2010). Bütçeyi Özerkleştirmek: Mali kurallar ve kurullar. Maliye Dergisi, 158(Ocak-Haziran), 547-569. https://ms.hmb.gov.tr/uploads/2019/09/29 .Ceyhun.GURKAN_YiGit. KARAHANOGULLARI . pdf.

Güzelsarı, S. (2004a). Kamu yönetimi disiplininde yeni kamu İşletmeciliği ve yönetişim yaklaşımları (Tartı̧̧ma Metinleri No. 66). Ankara: Ankara Üniversitesi Siyasal Bilgiler Fakültesi. https://sbfdergi.ankara.edu.tr/ dergi/tartisma/2004/selime-guzelsari.pdf.

Güzelsarı, S. (2004b). Yeni kamu Isşletmeciliği ve yönetişim yaklaşımları. Ankara: İmaj Yayıncılık.

Habernas, J. (2010). Kamusalliğın yaprsal dönüşümü (T. Bora ve M. Sancar, Çev.). İstanbul: İletişim Yayınları.

Harmes, A. (2006). Neoliberalism and multilevel governance. Review of International Political Economy, 13(5), 725-749. doi:10.1080/09692290600950621

James, O. (2005). The rise of regulation of the public sector in the united kingdom. Sociologie du Travail, 47(3), 323-339. doi:10.1016/j.soctra.2005.06.011

Jordana, J., ve Levi-Faur, D. (2004). The politics of regulation in the age of governance. İçinde: J. Jordana ve D. Levi-Faur (Ed.), The politics of regulation: Institutions and regulatory reforms for the age of governance (pp. 1-28). Cheltenham: Edward Elgar.

Kahraman, H. (2005). Türkiye'de Bağımsız Düzenleyici Kurum (BDK)'ların İdari ve Mali Özellikleri. Vergi Dünyası, Şubat. http://www.vergidunyasi .com.tr/Makaleler/3528.

Kalfa, C., ve Ataay, F. (2008). Yönetişim: Devlet toplum ilişkilerinde yeni bir aşama. Journal of the Cukurova University Institute of Social Sciences, 17(3), 229-240. https://dergipark.org.tr/tr/ pub/cusosbil/issue/4380/60078.

Karacan, A. İ. (2001). Özerk kurumların özerkliği. Rekabet Dergisi, 8(7), 3-62. http://www.rekabet .gov.tr/Dosya/dergi/8-pdf.

Karahanoğulları, O. (2004). Fransa. İçinde: B. A. Güler vd. (Ed.), Kamu yönetimi Ülke Incelemeleri (pp. 21-82). Ankara: Ankara Üniversitesi Siyasal Bilgiler Fakültesi.

Karasu, K. (2004). İngiltere. İçinde: B. A. Güler vd. (Ed.), Kamu yönetimi Ülke Incelemeleri (pp. 91177). Ankara: Ankara Üniversitesi Siyasal Bilgiler Fakültesi.

Kaya, A. (2004). Bağımsız ve düzenleyici Üst kurullar. Konya: Ĕ̆itim Kitabevi.

Kestane, D. (2002). Kamu kesiminde idari kuruluşların genel görünümü ve idari yapıda yeni organizasyonlar olarak bağımsız idari otoriteler (üst kurullar). Maliye Dergisi, 139 (Ocak-Nisan), 27-50. https://ms.hmb.gov.tr/uploads/2019/ 12/img-139.pdf.

Kjaer, A. M. (2004). Governance. Cambridge: Polity Press.

Lane, J.-E. (2001). Deregulation is not reregulation. İçinde: E. Svindland ve A. Midttun (Ed.), Approaches and dilemmas in economic regulation (pp. 171-189). London: Palgrave Macmillan UK.

Majone, G. (1994). The rise of the regulatory state in europe. West European Politics, 17(3), 77-101. 
doi:10.1080/01402389408425031

Majone, G. (1996). Regulating europe. London: Routledge.

Müftüoğlu, T. (2001). Ekonomi politikalar bağlamında regülasyon (Yayımlanmamış Konferans Bildirisi). Ankara: Regülasyon ve Rekabet Sempozyumu.

Morange, J. (1998). Fransa'da bağımsız Idari otoriteler (C. Atay, Trans.). İstanbul: Alkım Yayınları.

Öniş, Z., ve Şenses, F. (2007). Global dynamics, domestic coalitions and a reactive state: Major policy shifts in post-war turkish economic development (Working Paper No. 20636). Ankara: METU Economic Research Center. doi:10.2139/ssrn.1019997

OECD. (2002). Oecd reviews of regulatory reform: United kingdom 2002. Paris: OECD Publishing. doi:10.1787/9789264199255-en

Sezen, S. (2002). The impact of globalization on the organization of public administration: Turkish case. Turkish Public Administration Annual, 27, 1-22. https://soc.kuleuven.be/io/cost/pub/ paper/Sezen.pdf.

Sezen, S. (2003). Türk kamu yönetiminde kurullar: Geleneksel yapılanmadan kopuş. Ankara: TODAİE Yayınları. https://www . academia.edu/ 2289636/Seriye_Sezen_T\%C3\%BCrk_Kamu_Y\%C3\% B6netiminde_Kurullar_Geleneksel_Yap\%C4\% B1lanmadan_Kopu\%C5\%9F_TODA\%C4\%BOE_Ankara _2003.

Sobacı, Z., ve Parlak, B. (2005). Kuram ve uygulamalarda kamu yönetimi; ulusal ve global perspektifler. İstanbul: Alfa Aktüel.

Syrett, K. (2003). Düzenleyici kurumlar: Yapıları ve sorunları (C. Emre, Trans.). Ankara: İmaj Yayıncılık.

Tan, T. (2000). Rekabet kurumunun uygulama alanı açısından kamu kuruluşlarının faaliyeti: Türkiye, fransa ve İtalya Örnekleri. Rekabet Dergisi(4). http://www.rekabet.gov.tr/Dosya/ dergi/4-pdf.

Tan, T. (2002). Bağımsız İdari otoriteler veya düzenleyici kurullar. Amme İdaresi Dergisi, 35(2), 11-37. http:// repository.bilkent.edu.tr/bitstream/ handle/11693/50616/Ba\%C4\%9F\%C4\%B1ms\%C4\% B1z_idari_otoriteler_veya_d\%C3\%BCzenleyici _kurullar.pdf? sequence $=1 \&$ is sllowed=y.

Thatcher, M. (2002). Delegation to independent regulatory agencies: Pressures, functions and contextual mediation. West European Politics, 25(1), 125-147. doi:10.1080/713601588

Thomas, S. (2001). Theory and practice of governance of the british electricity industry. International Journal of Regulation and Governance, 1(1), 1-24. http://bookstore.teri.res .in/docs/journals/ijrg\%201-1(all). pdf.

Uçkan, . (2003). E-devlet, e-demokrasi ve türkiye. İstanbul: Literatür Yayınları.

Ulusoy, A. (1999). Bağımsız İdari kurumlar. Danıştay Dergisi. https://www.danistay.gov .tr/upload/yayinlar/05_12_2018_114012.pdf.
Ulusoy, A. (2003a). Bağımsız İdari otoriteler. Ankara: Turhan Kitabevi.

Ulusoy, A. (2003b). Regülasyon kurumları hakkında genel bir değerlendirme. Ankara Barosu Dergisi, 57(2), 45-60. http://www. ankarabarosu.org.tr/siteler/ ankarabarosu/tekmakale/2000-2/4.pdf.

World Bank. (1989). From crisis to sustainable growth - sub saharan africa: a long-term perspective study. Washington, D.C: World Bank Group. http://documents.worldbank.org/ curated/en/498241468742846138/From-crisis -to-sustainable-growth-sub-Saharan-Africa -a-long-term-perspective-study.

World Bank. (1992). Governance and development. Washington, D.C: World Bank Group. http://documents.worldbank.org/ curated/en/604951468739447676/Governance -and-development.

World Bank. (1994). Governance - the World Bank's experience. Washington, D.C: World Bank Group. http://documents.worldbank.org/ curated/en/711471468765285964/Governance -the-World-Banks-experience.

Yılmaz, Y. (2005). Fransa'da bağısız İdari otoriteler. Askeri Yüksek İdare Mahkemesi Dergisi(20).

Zengin, O. (2009). Günümüz kamu yönetiminde Ön plana Çıkan yaklaşımlar. İçinde: B. Övgün (Ed.), Kamu yönetimi: Yapı İşleyiş reform. Ankara: Ankara Üniversitesi Siyasal Bilgiler Fakültesi. http://yonetimbilimi.politics . ankara.edu .tr/wp-content/uploads/sites/732/2019/12/ kamuyonetimiyapi.pdf. 


\title{
Independent Administrative Authorities in the Framework of the Changing Role of the State: A Comparative Analysis
}

\author{
NaĞMe Buse ŞEneR (ib ${ }^{1}$ \\ Received:03.06.2020; Revised:23.06.2020; Accepted:29.06.2020
}

\begin{abstract}
As of the last quarter of the twentieth century, the accumulation regime changed, and the economic policies were reshaped within the change. In this period, the new liberal policies have showed themselves in many areas, especially in the economic field, thus it has brought a change in the understanding of the state and has also revealed significant structured bodies such as independent regulatory authorities in the field of public administration. These authorities are the embodiment of this new approach. In this study, primarily the transformation process of the state has been examined in an historical frame. The restructuring of independent regulatory authorities, played an important role in the public hierarchy during this transformation since the end of the twentieth century, has been discussed. The structure of these institutions in Turkey has also been analyzed, including comparative analysis of the selected countries and groups of countries.
\end{abstract}

JEL codes: F02, G28, G38, H10

Keywords: The Changing Role of the State, Independent Administrative Authorities, Neoliberalism

\section{Extended Summary}

By the last quarter of the twentieth century, the congestion of the capitalist system surfaced again, revealing the fact that a change is necessary in the accumulation regime. Economies response for this problem was initiating the withdrawal of the state, played an active role up until this point, from market processes. The role of nationstate has changed, and the state has begun to perform as 'a regulator-auditor' in the market economy compared to before. The change in the character of state after 1980's brought in a new institutional structure. Independent regulatory authorities can be

${ }^{1}$ Graduate School of Social Sciences, Ankara University, Ankara, Turkey. (e-mail: nbsener@gmail.com) called one of the most significant structures for the period of change. Even though there were some examples and implications before, independent administrative authorities have acquired their predominant roles in public administration after this period.

Previously, the historical development process of these institutions, which play an increasing role in the administrative structure, is discussed in the study. Historically the first independent regulatory authority organization appeared in the USA. This first authority emerged in line with the neoliberal approach with the aim of preventing interference in the market economy and preventing multi-headedness. Even though Keynesian 
economy and nationalization was the common and prominent policy for the rest of the world, USA preferred to regulate the market by independent regulatory authorities. The spread of independent authorities, which have been actively taking part in USA since the beginning of the century, for the rest of the world has been accompanied with the spread of new liberal policies. International organizations also highlighted these structures in this process and required the existence of these structures for the functionality of the market system.

These institutions became widespread in global scale without considering domestic dynamics of the countries but only taking references of the other countries' examples with quick adjustments as in Turkey. Because of that, the positive effects expected from the institutions are not be obtained. The structures, which reveal this situation, examined in an historical perspective including country comparisons in the study.

In this perspective, the independent administrative authorities in Turkey have been developed gradually in the public administration. Being the first independent authority, the CMB continued to be the first and the only one for more than ten years. The wind of change which was begun in the 1980s in the world has been started to be seen its affect after 1990s in the country and therefore, implementations of widespread privatization practices and establishment of independent administrative authorities, and attempts preventing the economy from direct intervention of the state came into life. When we analyzed the independent administrative authority practices in the country, it is seen that these institutions are included into the system as a result of global developments and by the directions of international organizations and even as a requirement of them from time to time, by totally ignoring internal dynamics. Even the legal background of these institutions came into force by copying other countries' practices. Because of the differences in administrative structure among countries, implementation problems have occurred therefore relevant institutional laws and other legal regulations have often been subject to change. In addition, considering current Turkish political and administrative structure, it is observed that the institutional status of these new structures is often discussed. A general assessment of these organizations in Turkey has been evaluated referring to the debate in the work. The discussions about institutional structuring, discussions about the place and where they should be in Turkish administrative structuring were included, and the current situation was evaluated.

As a result of these evaluations, these institutions- still the subject of debate of their places in the administrative structurecan be evaluated as a necessity for regulation in the system not only in Turkey but also for other countries, it is also evaluated it is important to be complied with the reasons of their existence while considering the local dynamics including global developments during this process. 